\title{
Numerical modelling on sorption kinetics of nitrogen species in wastewater-applied agricultural field
}

\author{
M. Berlin ${ }^{1}$. G. Suresh Kumar ${ }^{2}$
}

Received: 7 December 2016 / Accepted: 1 November 2018 / Published online: 8 November 2018

(c) The Author(s) 2018

\begin{abstract}
A one-dimensional numerical model is developed to simulate the nitrogen species in wastewater-applied agricultural field to investigate the effect of various isotherms of ammonium nitrogen and nitrate nitrogen. Results suggest that the ammonium nitrogen concentration reaches up to the depth of 40,25 and $16 \mathrm{~cm}$ due to the linear, Freundlich and Langmuir isotherms of ammonium nitrogen, which is corresponding to the reduction in migration depth up to $37 \%$ by Freundlich isotherm and 55\% by Langmuir isotherm as compared with linear isotherm. Similarly, the peak concentration of $25,15 \mathrm{and} 12 \mathrm{mg} / \mathrm{l}$ of nitrate nitrogen is observed during linear, Freundlich and Langmuir isotherms of $\mathrm{NH}_{4}-\mathrm{N}$, respectively. Further, the results show that $4 \%$ peak concentration reduction is experienced for $\mathrm{NO}_{3}-\mathrm{N}$ due to the linear $\mathrm{NH}_{4}-\mathrm{N}$ sorption alone, $7 \%$ peak reduction is observed for $\mathrm{NO}_{3}-\mathrm{N}$ concentration by Freundlich $\mathrm{NH}_{4}-\mathrm{N}$ sorption alone, and $12.5 \%$ peak reduction is monitored for $\mathrm{NO}_{3}-\mathrm{N}$ concentration due to Langmuir $\mathrm{NH}_{4}-\mathrm{N}$ sorption alone compared with the combination of Freundlich $\mathrm{NO}_{3}-\mathrm{N}$ sorption. The numerical results suggest that the combination of Langmuir isotherm of $\mathrm{NH}_{4}-\mathrm{N}$ and Freundlich isotherm of $\mathrm{NO}_{3}-\mathrm{N}$ is identified as a best combination of isotherm scenario, which mitigates the $\mathrm{NO}_{3}-\mathrm{N}$ contamination in groundwater resources.
\end{abstract}

Keywords Nitrogen species · Numerical modelling · Linear isotherm · Freundlich isotherm · Langmuir isotherm · Unsaturated porous media

\section{Introduction}

Groundwater contamination is an important concern due to the problem of soil contamination. Currently, groundwater is identified as the largest available freshwater source and which is under serious risk on maintaining its quality and quantity because of various anthropogenic activities (El Alfy 2012; Rahnama and Zamzam 2013). The nitrogen species concentration released from the wastewater- or fertilizer-applied agricultural fields can potentially affect the subsurface in terms of groundwater contamination and possible risk associated with the human health (Chen et al.

M. Berlin

berlin1982@gmail.com

G. Suresh Kumar

gskumar@iitm.ac.in

1 Department of Civil Engineering, National Institute of Technology, Arunachal Pradesh, Yupia, Papumpare, Arunachal Pradesh 791112, India

2 Department of Ocean Engineering, Indian Institute of Technology, Madras, Chennai 36, India
2007). Ammonium nitrogen, nitrite nitrogen, nitrate nitrogen and nitrogen gas are the major nitrogen species present in the aqueous phase. Additional nitrate nitrogen in drinking water may cause methaemoglobinaemia, called blue baby disease in new born infants (Lin and Wu 1996; Akosman and Ozdemir 2010). The state-of-the-art modelling of nitrogen species in soil is accounted by the classical transport parameters such as advection, diffusion and reaction. Among the transport parameters, sorption is recognized as a most efficient, promising and a predominant process in transport of nitrogen species in soil (Antonopoulos 1993; Lee et al. 2006). Modelling efforts to conceptualize the fate and their transport of nitrogen species in the unsaturated soil system depends largely on understanding the leading mass transfer mechanism, particularly sorption (Cahn et al. 1992; Sharifnia et al. 2016).

Sorption process considers a solid phase and liquid phase interaction to adsorb the sorbate species (liquid phase) onto the solid and bound thereby different mechanisms due to higher affinity. The partitioning (sorption or desorption) of any contaminant between aqueous and sorbed phases is described by the solid-liquid phase distribution (partition) 
coefficient (Liu et al. 1991). The accurate description of the sorption process of a contaminant is important to access the movement of solute in the subsurface and groundwater due to the sorption process. A general method for resembling solute retardation by sorption in subsurface system is the linear equilibrium model, which is the simplest sorption model (Faust and Mercer 1980; Pinder 1984). The first-order reversible kinetic model (Lapidus and Amundson 1952) and the two-region/two-site model (Karickhoff 1980) have been used effectively to describe the transport of various solutes that interact with porous media. The effect of sorption characteristics is carried out earlier on heterogeneous porous formation also (Sekhar et al. 2006; Suresh Kumar et al. 2008; Suresh Kumar 2009).

Adsorption equilibrium (the ratio between the adsorbed amount and the remaining in the solution) is recognized when an aqueous phase has been contacted with the solid phase for adequate time (Kumar and Sivanesan 2007; Ghiaci et al. 2004). A wide range of equilibrium isotherm models have been formulated based on three fundamental approaches such as kinetic equilibrium, thermodynamics and potential theory (Langmuir 1916; 1968; Myers and Prausnitz 1965; Dubinin 1960). Langmuir, Freundlich, Brunauer-Emmett-Teller (BET), Redlich- Peterson, Dubinin-Radushkevich, Temkin, Toth, Koble-Corrigan, Sips, Khan, Hill, Flory-Huggins and Radke-Prausnitz are some of the equilibrium isotherms (Malek and Farooq 1996). There are few models such as Sips, Toth, Koble Corrigan, Khan, Radke Prausnitz isotherms developed based on the combination equilibrium isotherms (Vijayaraghavan et al. 2006; Sips 1948; Toth 1971; Koble and Corrigan 1952; Khan et al. 1997). A number of researchers have been promoted to examine the applicability of linear and nonlinear isotherm models in describing the adsorption of various contaminants (Foo and Hameed 2010). Hence, the choice of the sorption model describing the partition between the soil and the pollutant of a specific site and the type of contaminant may have a great influence on the transport modelling results.

Generally, ammonium anion can be restrained due to the adsorption process with negatively charged cation such as sediment and soil particles as compared with other nitrogen species (Lee et al. 2006; Berlin et al. 2014a, b; Almasri and Kaluarachchi 2007). Many research studies show that the ammonium nitrogen sorption is followed by the linear adsorption isotherm (Mehran et al. 1984; Matschonat and Matzner 1995; Lunn et al. 1996; Morell et al. 1996; Birkinshaw and Ewen 2000; Saadi and Maslouhi 2003; Jellali et al. 2010; Ranjbar and Jalali 2013). Similarly, few studies confirm that the ammonium sorption can be followed by linear Freundlich-type isotherm (Lafolie 1991; Rahil and Antonopoulos 2007; Eturki et al. 2012; Moradzadeh et al. 2014; Sharifnia et al. 2016; Buragohain et al. 2013; Kizito et al. 2015). Few studies further suggest that the ammonium sorption may follow the Langmuir isotherm also (DeSimone and Howes 1998; Eturki et al. 2012; Sharifnia et al. 2016; Buragohain et al. 2013; Kizito et al. 2015). Even though the nitrate has less sorption affinity with soil particles due to negative charge, some studies have proved that it can get adsorbed by soil particles. Generally, the nitrate sorption phenomena may follow Freundlich isotherm (Cahn et al. 1992; Ozturk and Bektas 2004; Akosman and Ozdemir 2010). In essence, the ammonium nitrogen is following linear, Freundlich and Langmuir isotherms and nitrate nitrogen is frequently following Freundlich isotherm. Although many experimental studies show evidence that the above isotherms are critically influencing the concentration of all nitrogen species, the influence of various sorption isotherms on all nitrogen species in the unsaturated zone using mathematical modelling has not been analysed extensively. Therefore, this paper examines the impact of various sorption isotherms on the transport of nitrogen species in unsaturated porous media using one-dimensional numerical modelling technique.

\section{Materials and methods}

\section{Mathematical model}

In order to study the impact of various sorption isotherms on nitrogen species transport in a wastewater-applied agricultural field, coupled flow and transport models are used to simulate the near-field scenario. The vertical movement of water under unsaturated condition in one-dimensional domain can be defined by Richard's model as articulated in Eqs. (1)-(3) (Soleimani et al. 2009).

$C(h) \frac{\partial h}{\partial t}=\frac{\partial}{\partial z} K\left(\frac{\partial h}{\partial z}\right)-\frac{\partial K}{\partial z}$,

$K=K_{s} S_{e}^{1 / 2}\left[1-\left(1-S_{e}^{1 / \eta}\right)^{\eta}\right]^{2}$,

$\theta_{w}=\theta_{r}+\frac{\theta_{s}-\theta_{r}}{\left(1+|\alpha h|^{\beta}\right)^{\eta}}$,

where $S_{e}=\frac{\theta_{w}-\theta_{r}}{\theta_{s}-\theta_{r}}, C(h)=\frac{\partial \theta_{w}}{\partial h}$ is the specific moisture capacity $(1 / L) ; h$ is the pressure head $(L) ; K$ is the unsaturated hydraulic conductivity $(L / T)$; $\mathrm{t}$ is the time $(T) ; z$ is the vertical depth $(L)$ positive downward; $K_{\text {sat }}$ is the saturated hydraulic conductivity $(L / T) ; \theta_{w}$ is the water content $\left(L^{3} / L^{3}\right) ; \theta_{s}$ is the saturated water content; $\theta_{r}$ is the residual water content; and $\alpha, \beta$ and $\eta$ are fitting parameters.

Since the diffusive movement of oxygen in gas phase and its mass transfer to aqueous phase are key processes in the 
unsaturated zone (Reible et al. 1989), the air phase oxygen concentration can be simulated using one-dimensional transport (Simunek and Suarez 1994) as expressed in Eq. (4).

$\theta_{g}\left[\frac{\partial}{\partial t}\left(\mathrm{O}_{2, g}\right)\right]=\theta_{g} D_{0} \frac{\partial}{\partial z}\left[\tau \frac{\partial \mathrm{O}_{2, g}}{\partial z}\right]+\omega\left(\mathrm{O}_{2}-\frac{1}{H} \mathrm{O}_{2, g}\right)$.

The tortuosity factor $(\tau)$ is a function of the air-filled porosity $\theta_{a}$ and the total porosity $\theta_{s}$ is estimated using the expression provided by Millington (1959) and the same is represented by Eq. (5).

$\tau=\frac{\theta_{a}^{7 / 3}}{\theta_{s}}$.

Moreover, the mass transfer between gaseous phase and water phase can be expressed by Henry's equilibrium law (Alfnes et al. 2004) as shown in Eq. (6).

$\theta_{w}\left[\frac{\partial}{\partial t}\left(\mathrm{O}_{2}\right)\right]_{\text {exchange }}=-\omega\left(\mathrm{O}_{2}-\frac{1}{H} \mathrm{O}_{2, g}\right)$,

where $\mathrm{O}_{2}$ is the concentration of dissolved oxygen $\left(\mathrm{ML}^{-3}\right)$; $\mathrm{H}$ is the Henry law constant; $\omega$ is the first-order mass transfer rate $\left(\mathrm{T}^{-1}\right) ; \mathrm{O}_{2, \mathrm{~g}}$ is the concentration of oxygen in the gas phase $\left(\mathrm{ML}^{-3}\right) ; \theta_{g}=\theta_{s}-\theta_{w}$, is the air content; and $D_{0}$ is the coefficient of gas diffusion $\left(\mathrm{L}^{2} \mathrm{~T}^{-1}\right)$.

Figure 1a illustrates the nitrogen transformation pathways with the subsoil environment in an agricultural field. In this study, various sorption isotherms of nitrogen species are considered along with different processes such as nitrogen transformation by microbes, variation of dissolved organic carbon (DOC) and dissolved oxygen (DO). Equations for nitrogen species and DOC due to nitrification and denitrification processes are expressed by Eqs. (7)-(10) (Reddy and Patrick 1975; Lee et al. 2006).

$r_{1}: \mathrm{NH}_{4}^{+}+\frac{3}{2} \mathrm{O}_{2}(\mathrm{aq}) \rightarrow \mathrm{NO}_{2}^{-}+\mathrm{H}_{2} \mathrm{O}+2 \mathrm{H}^{+}$,

$r_{2}: \mathrm{NO}_{2}^{-}+\frac{1}{2} \mathrm{O}_{2}(\mathrm{aq}) \rightarrow \mathrm{NO}_{3}^{-}$,

$r_{3}: \mathrm{CH}_{2} \mathrm{O}+\frac{4}{5} \mathrm{NO}_{3}^{-} \rightarrow \frac{2}{5} \mathrm{~N}_{2}+\frac{4}{5} \mathrm{HCO}_{3}^{-}+\frac{1}{5} \mathrm{CO}_{2}(\mathrm{aq})+\frac{1}{5} \mathrm{H}_{2} \mathrm{O}$,

$\mathrm{r}_{4}: \mathrm{CH}_{2} \mathrm{O}+\mathrm{O}_{2}(\mathrm{aq}) \rightarrow \mathrm{CO}_{2}(\mathrm{aq})+\mathrm{H}_{2} \mathrm{O}$.

The dynamic form of the above reaction equations is provided by Eqs. (11)-(14) (Lee et al. 2006).

$r_{1}=\mu_{\max }^{\mathrm{nit1}} X_{1}\left[\frac{k_{b 1}}{k_{b 1}+\mathrm{X}_{1}}\right]\left[\frac{\mathrm{NH}_{4}-\mathrm{N}}{K_{\left(\mathrm{NH}_{4}-\mathrm{N}\right)}+\mathrm{NH}_{4}-\mathrm{N}}\right]\left[\frac{\mathrm{O}_{2}}{K_{O_{2}}+\mathrm{O}_{2}}\right]$, $r_{2}=\mu_{\max }^{\mathrm{nit} 2} X_{2}\left[\frac{k_{b 2}}{k_{b 2}+\mathrm{X}_{2}}\right]\left[\frac{\mathrm{NO}_{2}-\mathrm{N}}{K_{\left(\mathrm{NO}_{2}-\mathrm{N}\right)}+\mathrm{NO}_{2}}\right]\left[\frac{\mathrm{O}_{2}}{K_{\mathrm{O}_{2}}+\mathrm{O}_{2}}\right]$,

$\begin{aligned} r_{3}= & \mu_{\max }^{\text {denit }} X_{3}\left[\frac{k_{b 3}}{k_{b 3}+\mathrm{X}_{3}}\right]\left[\frac{k_{\mathrm{O}_{2 I}}}{k_{\mathrm{O}_{2 I}}+\mathrm{O}_{2}}\right]\left[\frac{\mathrm{CH}_{2} \mathrm{O}}{K_{\mathrm{CH}_{2} \mathrm{O}}+\mathrm{CH}_{2} \mathrm{O}}\right]_{(13)} \\ & {\left[\frac{\mathrm{NO}_{3}-\mathrm{N}}{K_{\left(\mathrm{NO}_{3}-\mathrm{N}\right)}+\mathrm{NO}_{3}-\mathrm{N}}\right] }\end{aligned}$

$r_{4}=\mu_{\max }^{\mathrm{oxid}} X_{3}\left[\frac{k_{b 3}}{k_{b 3}+X_{3}}\right]\left[\frac{\mathrm{CH}_{2} \mathrm{O}}{K_{\mathrm{CH}_{2} \mathrm{O}}+\mathrm{CH}_{2} \mathrm{O}}\right]\left[\frac{\mathrm{O}_{2}}{K_{\mathrm{O}_{2}}+\mathrm{O}_{2}}\right]$,

where $r_{1}$ is the substrate utilization rate by ammonium oxidation process $(\mathrm{mg} /(1$ day $)) ; r_{2}$ the substrate utilization rate by nitrite oxidation process (mg/(1 day)); $\mu_{\max }^{\text {nit1 }}$ the maximum substrate utilization rate for nitrification ( $1 /$ day); $\mu_{\max }^{\text {nit2 }}$ the maximum substrate utilization rate for nitrification (1/day); $X_{1}$ the ammonia-oxidizing autotrophic biomass concentration ( $\mathrm{mg} / \mathrm{l}) ; X_{2}$ the nitrite-oxidizing autotrophic biomass concentration (mg/l); $K_{\left(\mathrm{NH}_{4}-\mathrm{N}\right)}, K_{\left(\mathrm{NO}_{2}-\mathrm{N}\right)}$ and $K_{\mathrm{O} 2}$ the half saturation constants for $\mathrm{NH}_{4}^{+}-\mathrm{N}, \mathrm{NO}_{2}^{-}-\mathrm{N}^{-}$and $\mathrm{O}_{2}(\mathrm{mg} / \mathrm{l}) ; k_{b 1}$ and $k_{b 2}$ are the ammonia-oxidizing and nitrite-oxidizing biomass inhibition constants $(\mathrm{mg} / \mathrm{l}) ; r_{3}$ is the substrate utilization rate by denitrification (mg/(l day)); $\mu_{\max }^{\text {denit }}$ the maximum substrate utilization rate by denitrification (1/day); $K_{\mathrm{CH} 2 \mathrm{O}}$ and $K_{\left(\mathrm{NO}_{3}-\mathrm{N}\right)}$ the half saturation constants for $\mathrm{CH}_{2} \mathrm{O}$ and $\mathrm{NO}_{3}^{-}-\mathrm{N}(\mathrm{mg} / \mathrm{l})$; $X_{3}$ the heterotrophic biomass concentration (mg/l); $k_{b 3}$ and $k_{O 2 \mathrm{I}}$ are the heterotrophic biomass and oxygen inhibition constants $(\mathrm{mg} / \mathrm{l}) ; r_{4}$ is the substrate utilization rate by denitrification ( $\mathrm{mg} /(1$ day $))$; and $\mu_{\max }^{\text {oxid }}$ the maximum substrate utilization rate for organic carbon oxidation (1/day).

The coupled transport equations for ammonium nitrogen, nitrite nitrogen, nitrate nitrogen, nitrogen gas and dissolved organic carbon in the agricultural field described by the above reaction kinetics and the respective partial differential equations are provided in Eqs. (15)-(19) (Lee et al. 2006).

$R_{\mathrm{NH}_{4}-\mathrm{N}} \frac{\partial\left[\mathrm{NH}_{4}-\mathrm{N}\right]}{\partial t}=\frac{\partial}{\partial z}\left(D \frac{\partial\left[\mathrm{NH}_{4}-\mathrm{N}\right]}{\partial z}\right)-\frac{\partial\left(v\left[\mathrm{NH}_{4}-\mathrm{N}\right]\right)}{\partial z}-r_{1}$,

$$
\begin{aligned}
R_{\mathrm{NO}_{2}-\mathrm{N}} \frac{\partial\left[\mathrm{NO}_{2}-\mathrm{N}\right]}{\partial t}= & \frac{\partial}{\partial z}\left(D \frac{\partial\left[\mathrm{NO}_{2}-\mathrm{N}\right]}{\partial z}\right)-\frac{\partial\left(v\left[\mathrm{NO}_{2}-\mathrm{N}\right]\right)}{\partial z} \\
& +\left[y_{\left(\mathrm{NO}_{2}-\mathrm{N}\right) /\left(\mathrm{NH}_{4}-\mathrm{N}\right)}\right] r_{1}-r_{2}
\end{aligned}
$$

$$
\begin{aligned}
R_{\mathrm{NO}_{3}-\mathrm{N}} \frac{\partial\left[\mathrm{NO}_{3}-\mathrm{N}\right]}{\partial t}= & \frac{\partial}{\partial z}\left(D \frac{\partial\left[\mathrm{NO}_{3}-\mathrm{N}\right]}{\partial z}\right)-\frac{\partial\left(v\left[\mathrm{NO}_{3}-\mathrm{N}\right]\right)}{\partial z} \\
& +\left[y_{\left(\mathrm{NO}_{3}-\mathrm{N}\right) /\left(\mathrm{NO}_{2}-\mathrm{N}\right)}\right] r_{2}-r_{3},
\end{aligned}
$$


Fig. 1 a Conceptual model for nitrogen cycle in subsurface system (Berlin et al. 2013). b Procedure to solve the coupled water flow, air flow and transport of nitrogen species, DOC and DO models in unsaturated porous media

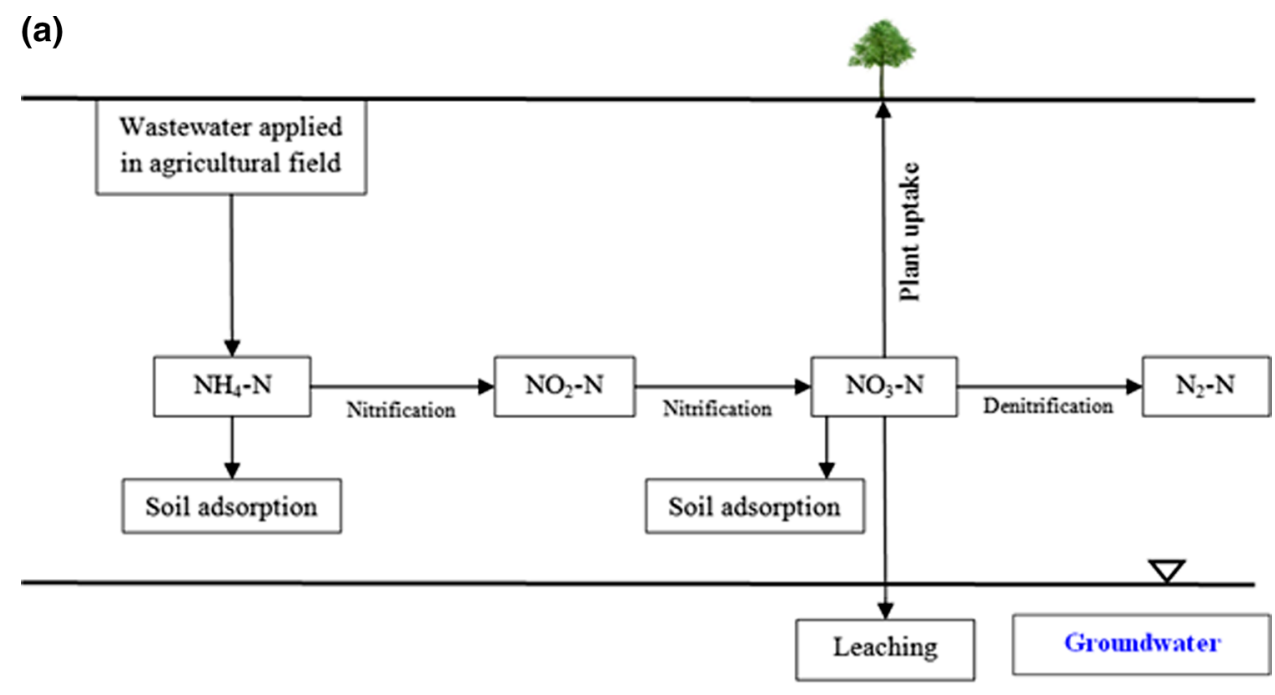

(b)

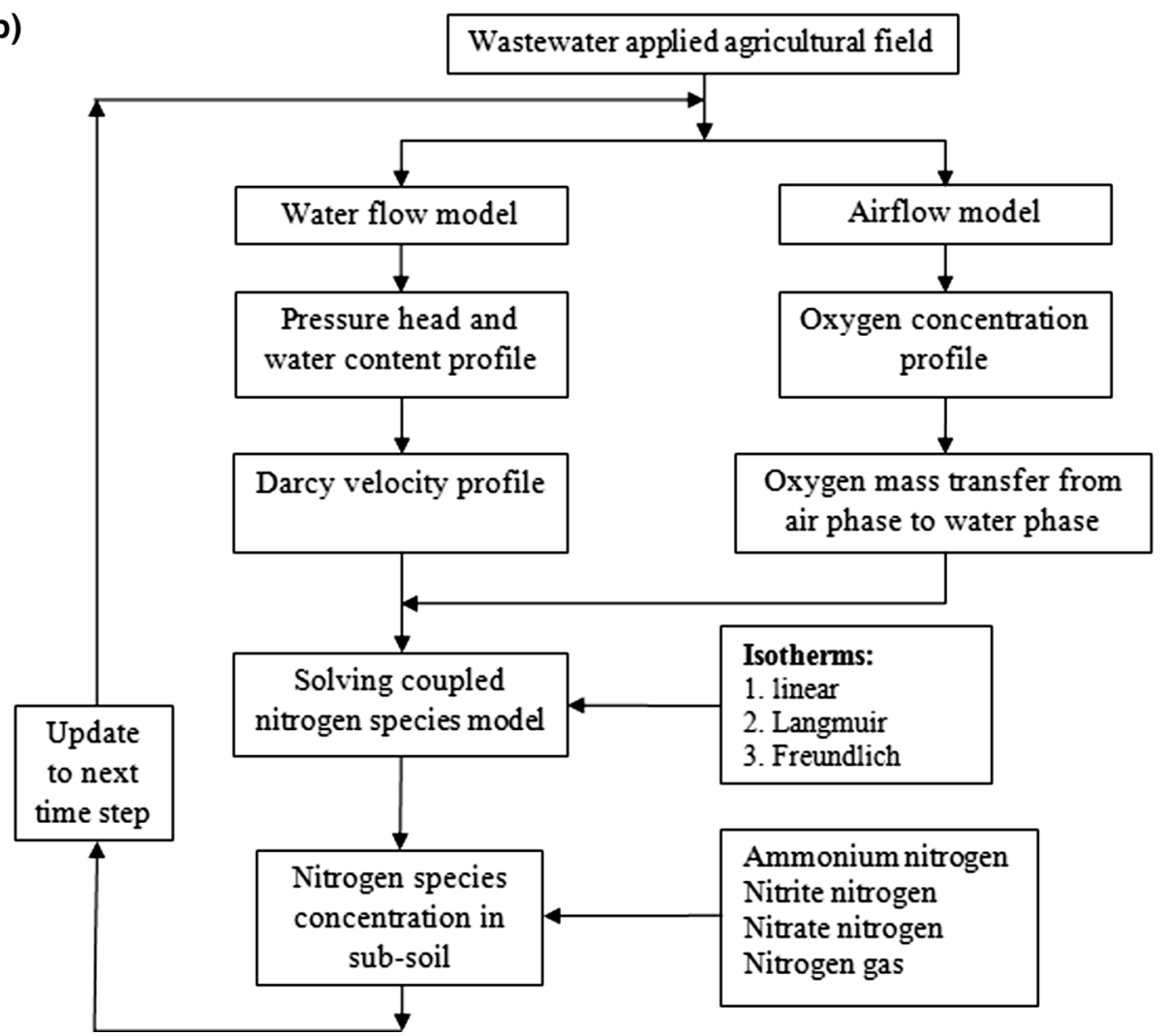

$R_{\mathrm{N}_{2}} \frac{\partial\left[\mathrm{N}_{2}\right]}{\partial t}=\frac{\partial}{\partial z}\left(D \frac{\partial\left[\mathrm{N}_{2}\right]}{\partial z}\right)-\frac{\partial\left(v\left[\mathrm{~N}_{2}\right]\right)}{\partial z}+\left[y_{\mathrm{N}_{2} /\left(\mathrm{NO}_{3}-\mathrm{N}\right)}\right] r_{3}$,

$R_{\mathrm{CH}_{2} \mathrm{O}} \frac{\partial\left[\mathrm{CH}_{2} \mathrm{O}\right]}{\partial t}=\frac{\partial}{\partial z}\left(D \frac{\partial\left[\mathrm{CH}_{2} \mathrm{O}\right]}{\partial z}\right)-\frac{\partial\left(v\left[\mathrm{CH}_{2} \mathrm{O}\right]\right)}{\partial z}-r_{4}$, where $\left[\mathrm{NH}_{4}-\mathrm{N}\right],\left[\mathrm{NO}_{2}-\mathrm{N}\right],\left[\mathrm{NO}_{3}-\mathrm{N}\right]$ and $\left[\mathrm{N}_{2}\right]$ represent the concentration of nitrogen species 1 (ammonium-nitrogen), species 2 (nitrite-nitrogen), species 3 (nitrate-nitrogen) and species 4 (nitrogen gas) (mg/l), respectively; $R_{\mathrm{NH}_{4}-\mathrm{N}}$, $R_{\mathrm{NO}_{2}-\mathrm{N}}, R_{\mathrm{NO}_{3}-\mathrm{N}}$, and $R_{\mathrm{N}_{2}}$ are the retardation factors for the various nitrogen species; $y_{\left(\mathrm{NO}_{2}-\mathrm{N}\right) /\left(\mathrm{NH}_{4}-\mathrm{N}\right)}, y_{\left(\mathrm{NO}_{3}-\mathrm{N}\right) /\left(\mathrm{NO}_{2}-\mathrm{N}\right)}$ and $y_{\mathrm{N}_{2} /\left(\mathrm{NO}_{3}-\mathrm{N}\right)}$ are the ratios of secondary substrate to primary substrate consumed, as determined by stoichiometry 
(mg/mg); $\left[\mathrm{CH}_{2} \mathrm{O}\right]$ represents the DOC concentration (mg/l); and $R_{\mathrm{CH}_{2} \mathrm{O}}$ is the retardation factor of DOC.

The one-dimensional transport equation for dissolved oxygen (DO) in unsaturated zone can be described (Lee et al. 2006; Alfnes et al. 2004; Berlin et al. 2015) as shown in Eq. (20).

$$
\begin{aligned}
R_{\mathrm{O}_{2}} \frac{\partial\left[\mathrm{O}_{2}\right]}{\partial t}= & \frac{\partial}{\partial z}\left(D \frac{\partial\left[\mathrm{O}_{2}\right]}{\partial z}\right)-\frac{\partial\left(v\left[\mathrm{O}_{2}\right]\right)}{\partial z} \\
& -\left[y_{\mathrm{O}_{2} /\left(\mathrm{NH}_{4}-\mathrm{N}\right)}\right] r_{1}-\left[y_{\mathrm{O}_{2} /\left(\mathrm{NO}_{2}-\mathrm{N}\right)}\right] r_{2} \\
& -\left[y_{\left.\mathrm{O}_{2} / \mathrm{CH}_{2} \mathrm{O}\right]}\right] r_{4}-\frac{\omega}{\theta_{w}}\left(\mathrm{O}_{2}-\mathrm{O}_{2, g}\right),
\end{aligned}
$$

where $\left[\mathrm{O}_{2}\right]$ represents the dissolved oxygen concentration (mg/l); $R_{\mathrm{O}_{2}}$ the retardation factor for dissolved oxygen; $y_{\mathrm{O}_{2} /\left(\mathrm{NH}_{4}-\mathrm{N}\right)}, y_{\mathrm{O}_{2} /\left(\mathrm{NO}_{2}-\mathrm{N}\right)}$ and $y_{\mathrm{O}_{2} / \mathrm{CH}_{4} \mathrm{O}}$ are the ratios of secondary substrate to primary substrate consumed as determined by stoichiometry $(\mathrm{mg} / \mathrm{mg}) ; \mathrm{O}_{2, \mathrm{a}}$ the term which relates the oxygen solubility in water from air and oxygen partial pressure $P_{\mathrm{O}_{2}}$; and $v=\frac{q}{\theta_{w}}$ is the pore water velocity and $q=-\mathrm{K}\left[\frac{\partial(h-z)}{\partial z}\right]$ is Darcy's water flux $(L / T)$.

The equations for the death rate and growth rate of autotrophic and heterotrophic bacteria are provided in Eqs. (21)-(23) (Lee et al. 2006).

$\frac{\mathrm{d} X_{1}}{\mathrm{~d} t}=Y_{1} r_{1}-X_{1} d_{1}$,

$\frac{\mathrm{d} X_{2}}{\mathrm{~d} t}=Y_{2} r_{2}-X_{2} d_{2}$,

$\frac{\mathrm{d} X_{3}}{\mathrm{~d} t}=Y_{3}\left(r_{3}+r_{4}\right)-X_{3} d_{3}$,

where $Y_{1}, Y_{2}$ and $Y_{3}$ are the yield coefficients for the autotrophic ammonia-oxidizing bacteria, autotrophic nitrite-oxidizing bacteria and heterotrophic bacteria (milligrams of biomass/milligrams of substrate), respectively, and $d_{1}, d_{2}$ and $d_{3}$ are death or maintenance rate constants (1/ day) of the ammonia-oxidizing, nitrite-oxidizing and heterotrophic biomass.

\section{Sorption isotherms}

A simple approach considering the local equilibrium assumption for sorption of the contaminant has been validated by the long contact time taken to establish solid-liquid partition. The effect of equilibrium sorption isotherm can be linear or nonlinear according to the variation in the interaction of the associated hydro-geological conditions (Sekhar and Suresh Kumar 2006; Sekhar et al. 2006; Suresh Kumar 2009; Vasudevan et al. 2015; Natarajan and Suresh Kumar 2015). On the other hand, the composite model for sorption is based on the assumption that both linear and nonlinear sorption can occur as the instantaneous response of the heterogeneous nature of the soil (Allen-King et al. 2002; Maraqa et al. 2011).

Many studies show that the ammonium nitrogen sorption is followed by the linear adsorption isotherm (Jellali et al. 2010; Ranjbar and Jalali 2013), Freundlich-type isotherm (Moradzadeh et al. 2014; Sharifnia et al. 2016; Buragohain et al. 2013; Kizito et al. 2015) and Langmuir isotherm (Buragohain et al. 2013; Kizito et al. 2015). Although the nitrate has less sorption affinity with soil particles due to negative charge, few studies have proved that nitrate follows Freundlich sorption isotherm (Cahn et al. 1992; Ozturk and Bektas 2004; Akosman and Ozdemir 2010). Hence, the sorption process has been considered for ammonium nitrogen and nitrate nitrogen in this study. The expressions and retardation factors for linear, Freundlich, Langmuir and the composite isotherms are given in Table 1.
Table 1 Expressions for sorption isotherms and corresponding retardation factors (Vasudevan et al. 2015)

\begin{tabular}{lll}
\hline Isotherm & Expression & Retardation factor \\
\hline Linear & $\frac{\partial S}{\partial t}=K_{d} \frac{\partial C}{\partial t}$. & $R_{1}=1+\frac{\rho_{b} K_{d}}{\theta_{w}}$. \\
Freundlich & $\frac{\partial S}{\partial t}=K_{f} \frac{\partial C n_{f}}{\partial t}$. & $R_{2}=1+\frac{\rho_{b} K_{f} n_{f} C_{f}-1}{\theta_{w}}$. \\
Langmuir & $\frac{\partial S}{\partial t}=\frac{\partial}{\partial t}\left[\frac{Q_{0} K_{l} C}{1+K_{l} C}\right]$. & $R_{3}=1+\frac{\rho_{b} K_{l} Q_{0}}{\theta_{w}\left(1+K_{l} C\right)^{2} .}$. \\
Linear+Freundlich & $\frac{\partial S}{\partial t}=f_{1} K_{d} \frac{\partial C}{\partial t}+f_{2} K_{f} \frac{\partial C n_{f}}{\partial t}$. & $R_{1}=1+f_{1} \frac{\rho_{b} K_{d}}{\theta_{w}}+f_{2} \frac{\rho_{b} K_{f} n_{f} C_{f}^{n_{f}-1}}{\theta_{w}}$. \\
Linear+Langmuir & $\frac{\partial S}{\partial t}=f_{1} K_{d} \frac{\partial C}{\partial t}+f_{2} \frac{\partial}{\partial t}\left[\frac{Q_{0} K_{l} C}{1+K_{l} C}\right]$ & $R_{1}=1+f_{1} \frac{\rho_{b} K_{d}}{\theta_{w}}+f_{2} \frac{\rho_{b} K_{l} Q_{0}}{\theta_{w}\left(1+K_{l} C\right)^{2}}$ \\
\hline
\end{tabular}

where $C$ is the concentration of ammonium or nitrate nitrogen in aqueous phase (mg/l); $S$ is the concentration of ammonium or nitrate nitrogen in solid phase $(\mathrm{mg} / \mathrm{mg}) ; \rho_{b}$ is the soil bulk density $\left(\mathrm{g} / \mathrm{cm}^{3}\right) ; k_{d}$ is the linear partitioning coefficient for corresponding nitrogen species $(1 / \mathrm{mg}) ; K_{f}$ is Freundlich adsorption constant $(1 / \mathrm{mg}) ; n_{f}$ is Freundlich isotherm constant; $Q_{0}$ is the sorption capacities of sorbent $(\mathrm{mg} / \mathrm{mg}) ; K_{l}$ is the Langmuir adsorption constant $(1 / \mathrm{mg})$; and $f_{1}$ and $f_{2}$ are partitioning factors 


\section{Numerical solution}

The systems of coupled partial differential equations describing unsaturated water flow, air transfer, microbial and nitrogen species along with the equilibrium sorption models, subjected to their initial and boundary conditions, are discretized by finite difference method and are solved using Thomas algorithm associated with the tri-diagonal matrix. The popular method to solve the water flow equation has been the implicit, finite difference with explicit linearization of $K(h)$ and $C(h)$ as shown in Eq. (24) (Van dam and Feddes 2000).

$\frac{h_{i}^{j+1}-h_{i}^{j}}{\Delta t^{j}}=\frac{K_{i-(1 / 2)}^{j}\left(\frac{\Delta h_{i-(1 / 2)}^{j+1}}{\Delta z}+1\right)-K_{i+(1 / 2)}^{j}\left(\frac{\Delta h_{i+1 / 2)}^{j+1}}{\Delta z}+1\right)}{C_{i}^{j} \Delta z}$,

where subscript $i$ is the node number and superscript $j$ is the time level. The values of the hydraulic conductivity $K$ and differential water capacity were taken at the old time level (explicit linearization). The spatial averages of $K$ were calculated using geometrical mean as the magnitude of unsaturated hydraulic conductivity varies over several orders of magnitude. This approach can be solved in the absence of involving iterations. Similarly, the air flow, nitrogen species transport and transformation model along with the sorption isotherms are solved by the fully implicit finite difference method. The resulting tri-diagonal systems of linear algebraic equations are solved using the Thomas algorithm. The total simulation time is divided into a finite number time intervals $(\Delta t)$. The value of cell width in the vertical direction $(\Delta z)$ is assumed to be $0.5 \mathrm{~cm}$, and the time interval $(\Delta t)$ is assumed to be $100 \mathrm{~s}$ in order to meet the numerical stability criteria. Firstly, the unsaturated flow model is solved to obtain the pressure head distribution in the unsaturated soil. Further, the air flow model is solved to obtain the air phase oxygen concentration. The obtained values of pressure head $h(z, t)$ are used to find $\theta(z, t), D(z, t)$ and $q(z, t)$, which appear in the mass transport of nitrogen species model. Then, the system of nitrogen species, dissolved oxygen in aqueous phase, dissolved organic carbon and microbial reaction equations are solved for the given initial and boundary conditions to get the concentration of nitrogen species in the vadose zone. Figure $1 \mathrm{~b}$ shows the numerical coupling of water flow, air flow, transport of nitrogen species, dissolved organic carbon and dissolved oxygen in the porous system.

\section{Initial and boundary conditions}

In the water flow model, the initial and bottom boundary pressure head value is taken as $-1000 \mathrm{~cm}$ and the top boundary pressure head value as $-75 \mathrm{~cm}$ (Mitchell and Mayer 1998). Similarly, for the air flow model representing the oxygen transport in an unsaturated zone, the initial and top boundary concentrations are 75.8 and $288 \mathrm{mg} / \mathrm{l}$ (Alfnes et al. 2004), respectively. The zero flux is used as the bottom boundary condition for oxygen. The initial concentration of all nitrogen species, dissolved organic carbon and dissolved oxygen is assumed to be $0 \mathrm{mg} / \mathrm{l}$. Similarly, the top boundary (soil surface) concentrations are fixed at 20.0, 0, 5.0, 0, 20 and $0 \mathrm{mg} / \mathrm{l}$ for ammonium nitrogen, nitrite nitrogen, nitrate nitrogen, nitrogen gas, dissolved organic carbon and dissolved oxygen, respectively. The nitrifying and denitrifying biomass concentrations are assumed to be $0.565 \mathrm{mg} / \mathrm{l}$ at the top boundary as well as initial condition (Lee et al. 2006). The concentration gradient is fixed to be zero for the bottom boundary condition for all nitrogen species, dissolved organic carbon, dissolved oxygen and all type of biomass (Lee et al. 2006).

\section{Results and discussion}

The effect of various isotherms on nitrogen species transport in unsaturated soil on wastewater-applied agricultural field is very important due to the groundwater quality concern. The present study focuses on the linear and nonlinear combinations of equilibrium and kinetic sorption in nitrogen species using a one-dimensional numerical modelling approach. The van Genuchten parameters $(\alpha, \beta, \eta)$ and other soil hydraulic parameters used for this study are given in Table 2. The bio-kinetic parameters required for the estimation of transformation rates and other parameters are given in Table 3. The developed numerical model is first validated with the experimental/numerical data from Bailey et al. (2013). It is observed from Fig. 2 that the simulated concentrations of nitrogen species from the present model with linear sorption are in good agreement with Bailey et al. (2013).

\section{Influence of ammonium nitrogen sorption on nitrogen species}

Figure 3 shows the effect of sorption and biodegradation on ammonium nitrogen and nitrate nitrogen in the wastewater-applied agricultural field. It is observed that in the absence of sorption and biodegradation process (base case) the transport of ammonium nitrogen reaches the maximum depth (Fig. 3a). Conversely, after introducing the sorption process the transport is retarded significantly. This shows that the affinity of ammonium nitrogen in the soil particles is predominant and in due course a significant reduction in the movement of the aqueous phase is observed. Further, the 
Table 2 Hydrodynamic properties and transport parameters for an unsaturated zone

\begin{tabular}{|c|c|c|c|}
\hline Parameter & Notation & Value & References \\
\hline Depth of unsaturated zone $(\mathrm{cm})$ & $L$ & 500 & Assumed \\
\hline Total simulation time (days) & - & 50 & Assumed \\
\hline Van Genuchten parameter $\left(\mathrm{cm}^{-1}\right)$ & $\alpha$ & 0.0335 & Mitchell and Mayer (1998) \\
\hline Van Genuchten parameter & $\beta$ & 2.0 & Mitchell and Mayer (1998) \\
\hline Van Genuchten parameter & $\eta$ & 0.5 & $1-(1 / \beta)$ \\
\hline Saturated water content $\left(\mathrm{m}^{3} / \mathrm{m}^{3}\right)$ & $\theta_{s}$ & 0.381 & Mitchell and Mayer (1998) \\
\hline Residual water content $\left(\mathrm{m}^{3} / \mathrm{m}^{3}\right)$ & $\theta_{r}$ & 0.102 & Mitchell and Mayer (1998) \\
\hline Saturated hydraulic conductivity $(\mathrm{cm} / \mathrm{s})$ & $K_{s}$ & 0.00922 & Mitchell and Mayer (1998) \\
\hline Soil bulk density $(\mathrm{mg} / \mathrm{l})$ & $\rho_{b}$ & $1.6 \times 10^{6}$ & Lee et al. (2006) \\
\hline Molecular diffusion coefficient $\left(\mathrm{cm}^{2} / \mathrm{h}\right)$ & $D_{m}$ & 0.012 & Overman (1975) \\
\hline Longitudinal dispersivity $(\mathrm{cm})$ & $\lambda_{L}$ & 5 & Assumed \\
\hline Diffusion coefficient of $\mathrm{O}_{2}$ in free air at $20^{\circ} \mathrm{C}\left(\mathrm{m}^{2} / \mathrm{sec}\right)$ & $D_{0}$ & $1.78 \times 10^{-5}$ & Lee et al. (2003) \\
\hline Mass transfer coefficient $\left(\right.$ day $\left.^{-1}\right)$ & $\omega$ & 5 & Alfnes et al. (2004) \\
\hline Linear partitioning coefficient of DOC (1/mg) & $K_{d \mathrm{CH}_{2} \mathrm{O}}$ & $1.5 \times 10^{-6}$ & Lee et al. (2006) \\
\hline Linear partitioning coefficient of $\mathrm{NH}_{4}-\mathrm{N}(1 / \mathrm{mg})$ & $K_{d \mathrm{NH}_{-} \mathrm{N}}$ & $0.34 \times 10^{-6}$ & Lee et al. (2006) \\
\hline Freundlich adsorption constant for $\mathrm{NH}_{4}-\mathrm{N}(1 / \mathrm{mg})$ & $K_{f \mathrm{NH}_{4}-\mathrm{N}}$ & $0.5445 \times 10^{-5}$ & Ranjbar and Jalali (2013) \\
\hline Freundlich isotherm constant for $\mathrm{NH}_{4}-\mathrm{N}$ & $n_{f \mathrm{NH}_{4}-\mathrm{N}}$ & 1.193 & Ranjbar and Jalali (2013) \\
\hline Langmuir sorption capacity for $\mathrm{NH}_{4}-\mathrm{N}$ (mg/mg) & $\mathrm{Q}_{0}$ & $2150.9 \times 10^{-6}$ & Buragohain et al. (2013) \\
\hline Langmuir adsorption constant for $\mathrm{NH}_{4}-\mathrm{N}(1 / \mathrm{mg})$ & $K_{l \mathrm{NH}_{4}-\mathrm{N}}$ & 0.0084 & Buragohain et al. (2013) \\
\hline Freundlich adsorption constant of $\mathrm{NO}_{3}-\mathrm{N}(1 / \mathrm{mg})$ & $K_{f \mathrm{NO}_{3}-\mathrm{N}}$ & $0.4 \times 10^{-6}$ & Akosman and Ozdemir (2010) \\
\hline Freundlich isotherm constant for $\mathrm{NO}_{3}-\mathrm{N}$ & $n_{f \mathrm{NO}_{3}-\mathrm{N}}$ & 1.239 & Akosman and Ozdemir (2010) \\
\hline Partitioning factors & $f_{1}, f_{2}$ & $0.5,0.5$ & Assumed \\
\hline
\end{tabular}

Table 3 Summary of Monod kinetics reaction parameters used for the present study

\begin{tabular}{|c|c|c|c|c|c|}
\hline Parameter & Unit & Value & Parameter & Unit & Value \\
\hline \multicolumn{6}{|c|}{ From Lee et al. (2006) } \\
\hline$\mu_{\max }^{\mathrm{nit1}}$ & (1/day) & 10 & $k_{b 1}$ & $(\mathrm{mg} / \mathrm{l})$ & 1 \\
\hline$\mu_{\max }^{\mathrm{nit} 2}$ & (1/day) & 10 & $k_{b 2}$ & $(\mathrm{mg} / \mathrm{l})$ & 1 \\
\hline$\mu_{\max }^{\mathrm{denit}}$ & (1/day) & 40 & $k_{b 3}$ & $(\mathrm{mg} / \mathrm{l})$ & 0.5 \\
\hline$\mu_{\max }^{\text {oxid }}$ & (1/day) & 30 & $d_{1}$ & (1/day) & 0.02 \\
\hline$K_{\mathrm{NH}_{4}-\mathrm{N}}$ & $(\mathrm{mg} / \mathrm{l})$ & 1 & $d_{2}$ & (1/day) & 0.02 \\
\hline$K_{\mathrm{NO}_{2}-\mathrm{N}}$ & $(\mathrm{mg} / \mathrm{l})$ & 1.8 & $d_{3}$ & (1/day) & 0.02 \\
\hline$K_{\mathrm{NO}_{3}-\mathrm{N}}$ & $(\mathrm{mg} / \mathrm{l})$ & 2.6 & $Y_{1}$ & & 0.45 \\
\hline$K_{\mathrm{O}_{2}}$ & $(\mathrm{mg} / \mathrm{l})$ & 0.77 & $Y_{2}$ & & 0.45 \\
\hline$K_{\mathrm{CH}_{2} \mathrm{O}}$ & $(\mathrm{mg} / \mathrm{l})$ & 40 & $Y_{3}$ & & 0.5 \\
\hline$k_{\mathrm{O}_{21}}$ & $(\mathrm{mg} / \mathrm{l})$ & 0.01 & & & \\
\hline
\end{tabular}

Calculated values

$\begin{array}{lll}y_{\left(\mathrm{NO}_{2}-\mathrm{N}\right) /\left(\mathrm{NH}_{4}-\mathrm{N}\right)} & \text { Based on stoichiometry } & 1 \\ y_{\left(\mathrm{NO}_{3}-\mathrm{N}\right) /\left(\mathrm{NO}_{2}-\mathrm{N}\right)} & & 1 \\ y_{\mathrm{N}_{2} /\left(\mathrm{NO}_{3}-\mathrm{N}\right)} & & 2 \\ y_{\mathrm{O}_{2} / \mathrm{CH}_{2} \mathrm{O}} & & 1.0657 \\ y_{\mathrm{O}_{2} /\left(\mathrm{NH}_{4}-\mathrm{N}\right)} & 2.285 \\ y_{\mathrm{O}_{2} /\left(\mathrm{NO}_{2}-\mathrm{N}\right)} & 2.285 \\ y_{\mathrm{O}_{2} / \mathrm{CH}_{2} \mathrm{O}} & 1.0657\end{array}$


Fig. 2 Validation of nitrogen species transport model for ammonium, nitrite and nitrate nitrogen concentration in unsaturated porous media

Fig. 3 Influence of sorption and biodegradation in a ammonium nitrogen and $\mathbf{b}$ nitrate nitrogen at the end of 10 days of wastewater application (refer to Tables 2 and 3 for other data)

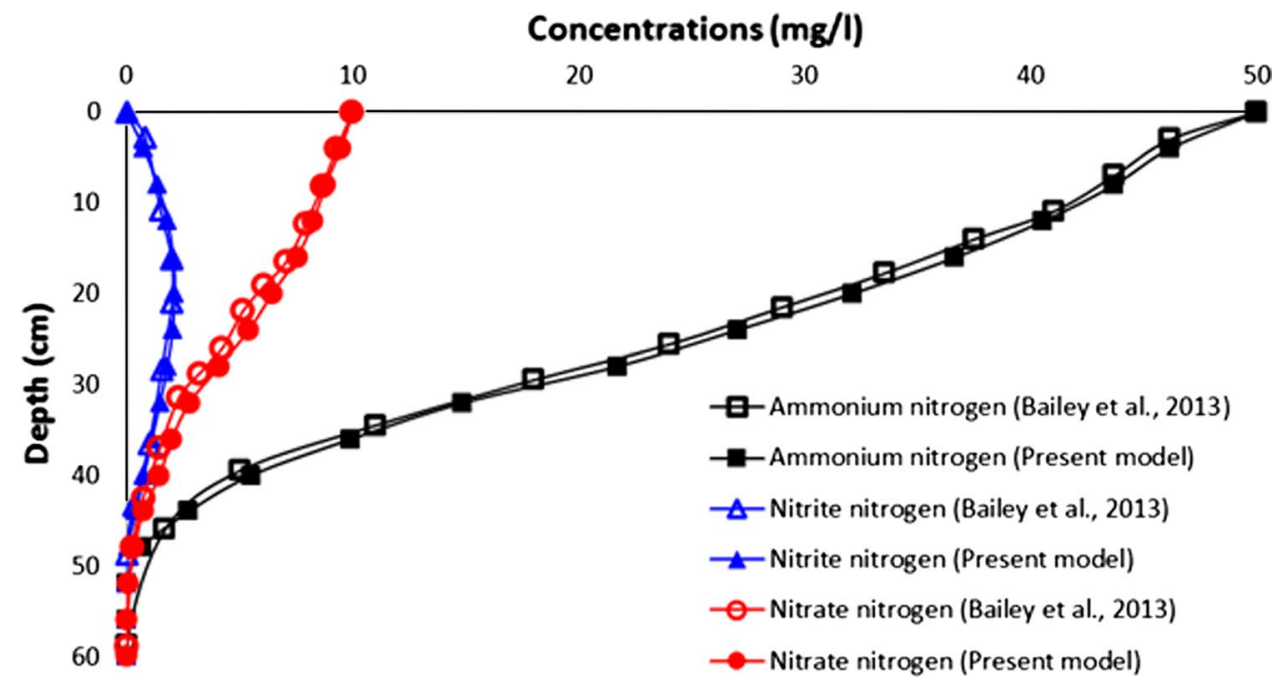

(a)

Ammonium Nitrogen Concentration ( $\mathrm{mg} / \mathrm{l}$ )
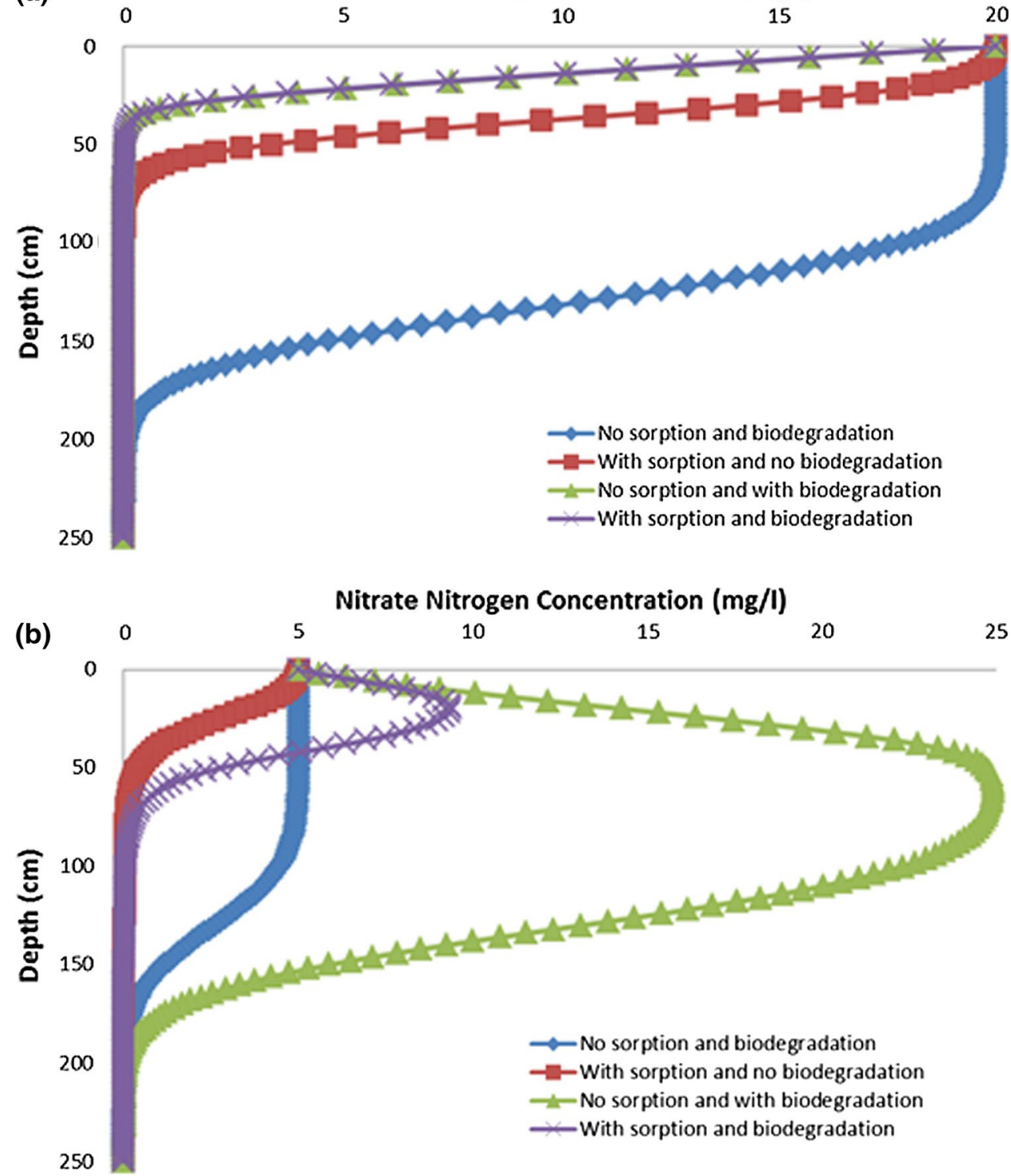
Fig. 4 Concentration profile for ammonium nitrogen with linear, Freundlich and Langmuir isotherms at the end of 50 days of wastewater application (refer to Tables 2 and 3 for other data)

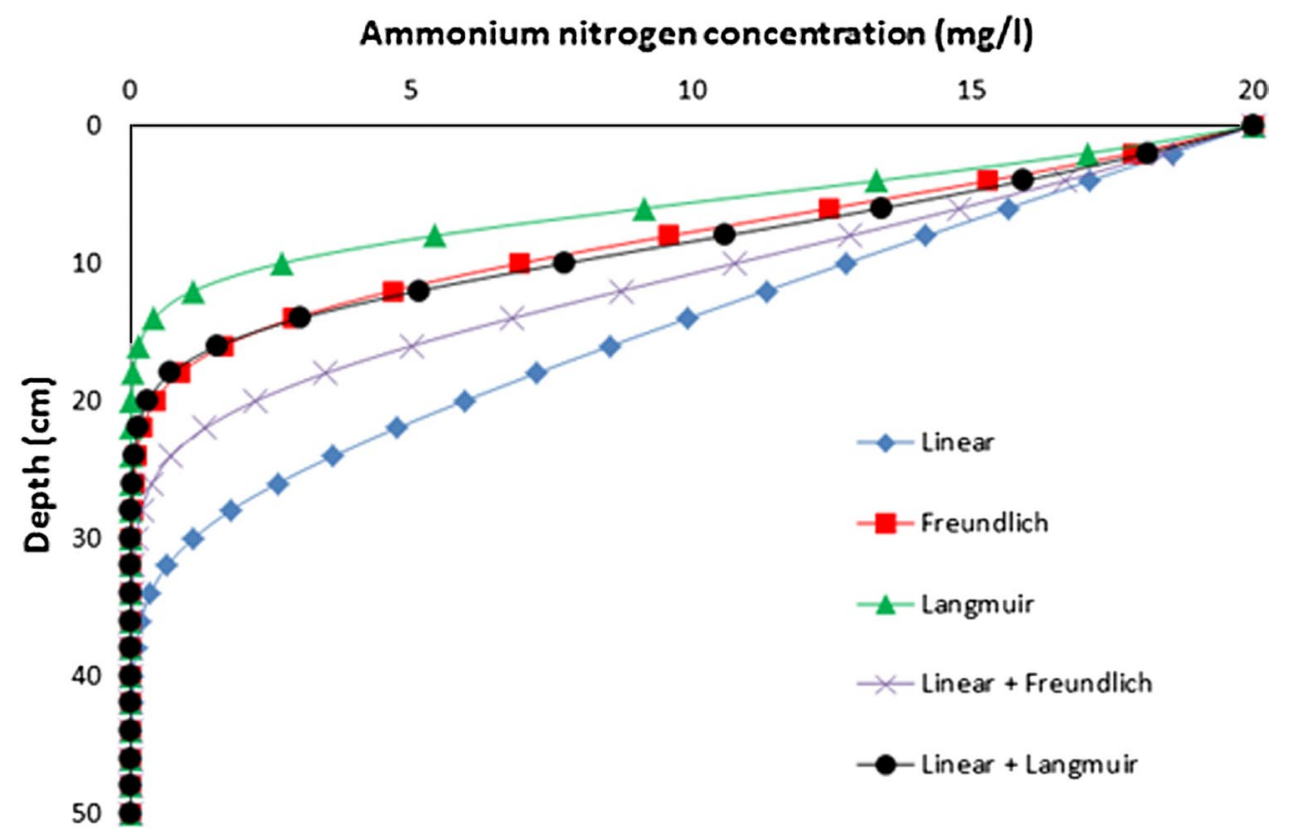

effect of biodegradation is also investigated in the absence of sorption process. The result shows that the degradation resulting from nitrification is highly inducing the availability of aqueous phase ammonium nitrogen. However, the combined effect of sorption and biodegradation is relatively similar to the effect with biodegradation alone. The effect of ammonium sorption is negligible as compared with biodegradation. Similarly, the effect of sorption and biodegradation on nitrate nitrogen is shown in Fig. 3b. It is observed that the individual effect of sorption and biodegradation of nitrate nitrogen is fairly similar to the ammonium nitrogen. But the synergistic effect of sorption and biodegradation is influencing more as compared with ammonium nitrogen. Hence, it can be concluded that the effects of sorption and biodegradation process become highly interrelated and essential when analysing the ammonium and nitrate nitrogen transport in unsaturated porous media.

Figure 4 provides the spatial variation of ammonium nitrogen concentration due to the sorption of ammonium nitrogen explained by linear, Freundlich, Langmuir isotherms and combined isotherms in the wastewater-applied agricultural field. It is observed that the linear sorption isotherm shows a least adsorption capacity as compared with Freundlich and Langmuir isotherms. The available concentration of $20 \mathrm{mg} / \mathrm{l}$ ammonium nitrogen at the soil surface has become $0 \mathrm{mg} / \mathrm{l}$ at $40 \mathrm{~cm}$ depth during linear isotherm. On the other hand, Freundlich and Langmuir isotherms produce higher sorption capacity and yield very high retardation on ammonium nitrogen concentration. Hence, the concentration of ammonium nitrogen reaches up to $25 \mathrm{~cm}$ depth for Freundlich isotherm and $16 \mathrm{~cm}$ depth for Langmuir isotherm. However, Langmuir isotherm has high influence on ammonium nitrogen sorption as compared with Freundlich as well as linear isotherm. This is mainly due to various partition coefficients of ammonium nitrogen with soil with the effect of corresponding isotherms. The linear isotherm partition coefficient $\left(0.34 \times 10^{-6} 1 / \mathrm{mg}\right)$ value has one order lower than Freundlich isotherm partition coefficient $\left(0.5445 \times 10^{-5} \mathrm{l} / \mathrm{mg}\right)$ and four orders lower than Langmuir isotherm $\left(0.84 \times 10^{-2} 1 / \mathrm{mg}\right)$. Moreover, Freundlich isotherm constant $\left(n_{f}\right)$ and Langmuir sorption capacity $\left(Q_{0}\right)$ are playing a predominant role on the retardation of ammonium nitrogen. The concentration profile of ammonium nitrogen reaches $0 \mathrm{mg} / \mathrm{l}$ at $30 \mathrm{~cm}$ depth from $20 \mathrm{mg} / \mathrm{l}$ at soil surface, implying that the combined effect of linear and Freundlich isotherms receives the effective (average) concentrations as compared with its individual concentration. A similar trend is also observed for linear and Langmuir isotherm mixture. Hence, it can be concluded that the effect of Langmuir isotherm has high sorption capacity than Freundlich and linear isotherm, while the combined effect does not have much influence on the variation of ammonium nitrogen.

Figure 5 shows the spatial variation of nitrate nitrogen concentration due to the sorption of ammonium nitrogen described by linear, Freundlich, Langmuir isotherms and combination of isotherms in the wastewater-applied agricultural field. The nitrate nitrogen concentration is increasing from $5 \mathrm{mg} / \mathrm{l}$ which is applied at the soil surface to 12 , 15 and $25 \mathrm{mg} / \mathrm{l}$ with Langmuir, Freundlich and linear isotherms, respectively, and decreasing thereafter with respect to the depth in all isotherm scenarios. The initial increase in all cases is due to the two-step nitrification process, where the ammonium nitrogen is converting to nitrate nitrogen. A

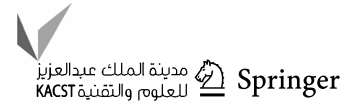


Fig. 5 Concentration profile for nitrate nitrogen with linear, Freundlich and Langmuir isotherms at the end of 50 days of wastewater application (refer to Tables 2 and 3 for other data)

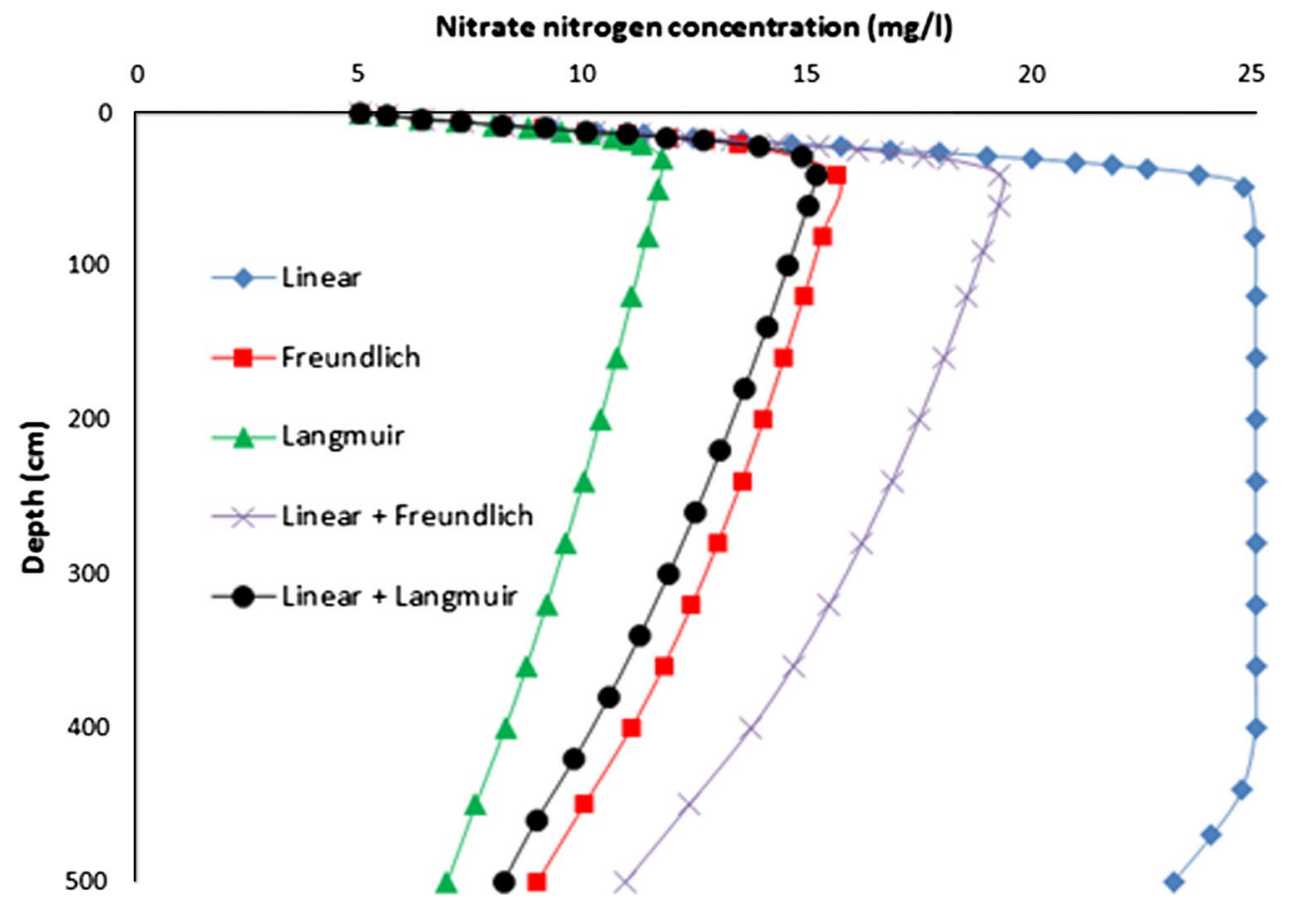

close observation between linear and all other isotherms at a depth of $50 \mathrm{~cm}$ implies that there is a strong reduction in the production of nitrate nitrogen for all isotherms except linear isotherm. This high concentration (25 mg/l) in nitrate nitrogen during linear isotherm is due to the plenty of available aqueous phase ammonium nitrogen, which is shown in Fig. 4. The reduced aqueous concentration of ammonium nitrogen during the Freundlich and Langmuir isotherms is directly affecting the production of nitrate nitrogen concentration, which is shown in Fig. 5. Further, the results show that the concentration of nitrate nitrogen due to the combined isotherms follows a similar trend which is observed in ammonium nitrogen concentration. As depth increases, the concentration of nitrate nitrogen is decreasing for Freundlich and Langmuir isotherms. For example, the concentration of nitrate nitrogen reaches 11.5 and $15 \mathrm{mg} / \mathrm{l}$ at $100 \mathrm{~cm}$ depth, 10 and $12.5 \mathrm{mg} / \mathrm{l}$ at $300 \mathrm{~cm}$ depth and 7 and $10 \mathrm{mg} / \mathrm{l}$ at $500 \mathrm{~cm}$ depth for Freundlich and Langmuir isotherms. However, there is not much reduction observed for linear isotherm with respect to depth due to the sufficiently available ammonium nitrogen for transformation. Thus, the Freundlich and Langmuir isotherms are serving better for reduction in groundwater contamination, especially at the large depths. From Figs. 4 and 5, it can be concluded that the linear sorption isotherm tends to overestimate the depth of penetration of ammonium nitrogen species in an unsaturated vertical soil
Fig. 6 Concentration profile for different nitrogen species with linear, Freundlich and Langmuir isotherms at the end of 50 days of wastewater application (refer to Tables 2 and 3 for other data)

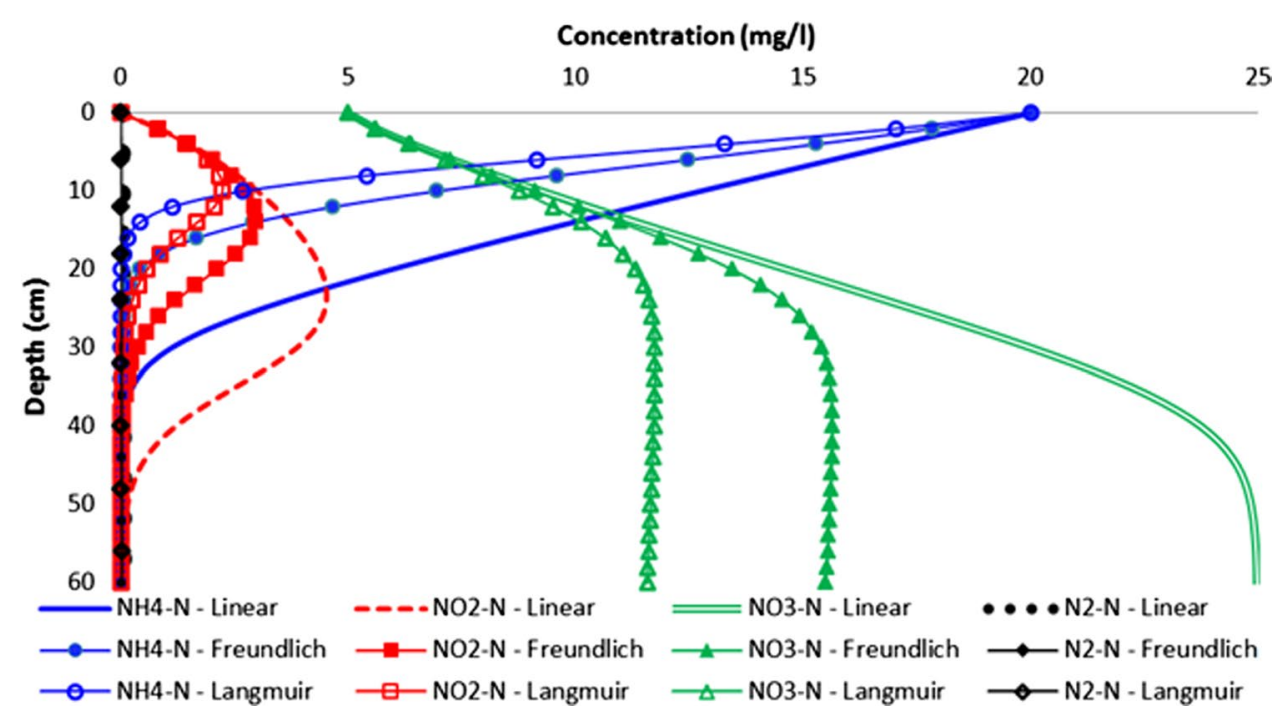


system with reference to Freundlich and Langmuir sorption isotherms, while the Langmuir sorption isotherm is associated with the least penetration depth of ammonium nitrogen species and subsequently indicates the maximum adsorption of ammonium species in the unsaturated system during its vertical downward migration. However, it is also noted that the overall adsorption pattern of ammonium nitrogen species nearly remains the same for all the sorption isotherms considered. It is interesting to note that the behaviour of Freundlich sorption isotherm and the coupled effect of linear and Langmuir sorption isotherms nearly remain the same. Thus, one can use Langmuir sorption exponent along with the linear isotherm in the absence of Freundlich sorption exponent. Linear sorption isotherm, in general, overestimates the concentration of ammonium nitrogen species at a given depth, and hence, nonlinear sorption isotherms using Freundlich and Langmuir need to be based on the nature of soil associated with the unsaturated system.

Figure 6 provides the spatial variation of ammonium nitrogen, nitrite nitrogen, nitrate nitrogen and nitrogen gas concentrations due to the sorption of ammonium nitrogen by linear, Freundlich and Langmuir isotherms in the wastewater-applied agricultural field. It is observed from Fig. 6 that the ammonium nitrogen concentration from $20 \mathrm{mg} / 1$ at soil surface is reduced to $0 \mathrm{mg} / \mathrm{l}$ at the depth of $40 \mathrm{~cm}$ in the presence of linear sorption. This ammonium nitrogen concentration reaches its asymptoticity after a depth of $40 \mathrm{~cm}$, implying that there is no addition or removal of mass from the nitrite nitrogen. At the same time, the nitrite nitrogen concentration reached the maximum concentration up to $4 \mathrm{mg} / \mathrm{l}$ at the depth of $30 \mathrm{~cm}$. This increase in concentration is due to the first stage of nitrification process due to the nitrifying bacteria in the presence of dissolved oxygen. It is also observed from Fig. 6 that the quantum of nitrate nitrogen keeps increasing with depth until it reaches its peak value followed by its asymptotic nature. The maximum concentration of $25 \mathrm{mg} / \mathrm{l}$ is observed after the depth of $50 \mathrm{~cm}$ due to the second-stage nitrification process in the presence of nitrifying bacteria with high dissolved oxygen concentration. Since the mass transfer of oxygen from air phase to water phase is high, the oxic condition allows the ammonium nitrogen to get fully transformed to nitrate nitrogen after the depth of $50 \mathrm{~cm}$. Conversely, no variation is observed for nitrogen gas profile due to the sufficient dissolved oxygen availability. Even though the heterotrophic bacteria are available in the system, the denitrification rate is diminished by the large dissolved oxygen concentration.

Further, the numerical results show that the ammonium nitrogen concentration becomes $0 \mathrm{mg} / \mathrm{l}$ at the depth of $25 \mathrm{~cm}$ in the presence of Freundlich isotherm. This shows a strong reduction in migration of ammonium nitrogen due to Freundlich isotherm as compared with linear isotherm $(0 \mathrm{mg} / \mathrm{l}$ at $40 \mathrm{~cm}$ depth). Similarly, the peak nitrite nitrogen is observed at the depth of $15 \mathrm{~cm}$ and reduced to $0 \mathrm{mg} / \mathrm{l}$ at the depth of $40 \mathrm{~cm}$. Further, the results show that the nitrate nitrogen concentration reaches its maximum value $(16 \mathrm{mg} / \mathrm{l})$ at the depth of $35 \mathrm{~cm}$ in the presence of Freundlich isotherm, whereas the concentration reaches $25 \mathrm{mg} / \mathrm{l}$ after the depth of $50 \mathrm{~cm}$. This shows that the available amount of ammonium nitrogen in aqueous phase is very high in the linear isotherm; in turn, a large amount of nitrate nitrogen is produced. In contrast, the sorbed concentration of ammonium nitrogen is increased in the case of Freundlich isotherm and finally the concentration of aqueous phase ammonium nitrogen is reduced. Therefore, the nitrate nitrogen production is diminished in the presence of Freundlich isotherm. However, there is no variation observed in nitrogen gas profile due to the highly oxic condition.

It is also observed from Fig. 6 that the ammonium nitrogen concentration reaches $0 \mathrm{mg} / \mathrm{l}$ at the depth of $18 \mathrm{~cm}$ in the presence of Langmuir isotherm. This is the least depth of penetration by ammonium nitrogen as compared with linear and Freundlich isotherms, which shows that Langmuir isotherm plays a predominant role on ammonium sorption between aqueous and solid phase. The complex interplay between the aqueous and solid phase of ammonium nitrogen shows the associate reduction in nitrite nitrogen and nitrate nitrogen concentration. This can be confirmed by penetration of nitrate nitrogen up to the depth of $25 \mathrm{~cm}$ in the presence of Langmuir isotherm. Further, it is noticed that a drastic deduction in depth $(30 \mathrm{~cm})$ of movement on nitrate nitrogen is also observed in the presence of Langmuir isotherm. It can be concluded from Fig. 6 that the peak concentration of nitrate nitrogen has reduced to $36 \%$ for Freundlich isotherm as compared with linear isotherm and $54 \%$ has been observed for Langmuir as compared with linear isotherm. This reduction indicates that the Langmuir isotherm is performing well on nitrate nitrogen reduction at deeper depths and the groundwater contamination by nitrate nitrogen is averted. Moreover, it is keenly observed from Fig. 6 that the ammonium nitrogen becomes zero after the depth of 40, 25 and $18 \mathrm{~cm}$ for linear, Freundlich and Langmuir isotherms and the peak values of nitrate nitrogen concentration are observed at the depth of 50,53 and $25 \mathrm{~cm}$. Additionally, it is observed that the ammonium nitrogen reduction and nitrate nitrogen increase are directly influenced by the nitrification process and the depth of penetration is directly correlated by the linear adsorption rate on ammonium nitrogen and the reduction in nitrate nitrogen concentration with depth is relatively fast in the case of Freundlich isotherm as compared with linear isotherm.

Figure 7 shows the sensitivity analysis for linear, Freundlich and Langmuir isotherm coefficients of ammonium nitrogen and its transport in the wastewater-applied agricultural soil. The linear partition coefficient value of $0.34 \times 10^{-6} 1 / \mathrm{mg}$ (base value) allows the concentration of 
Fig. 7 Sensitivity analysis of linear, Freundlich and Langmuir isotherm coefficients for ammonium nitrogen concentration (refer to Tables 2 and 3 for other data)

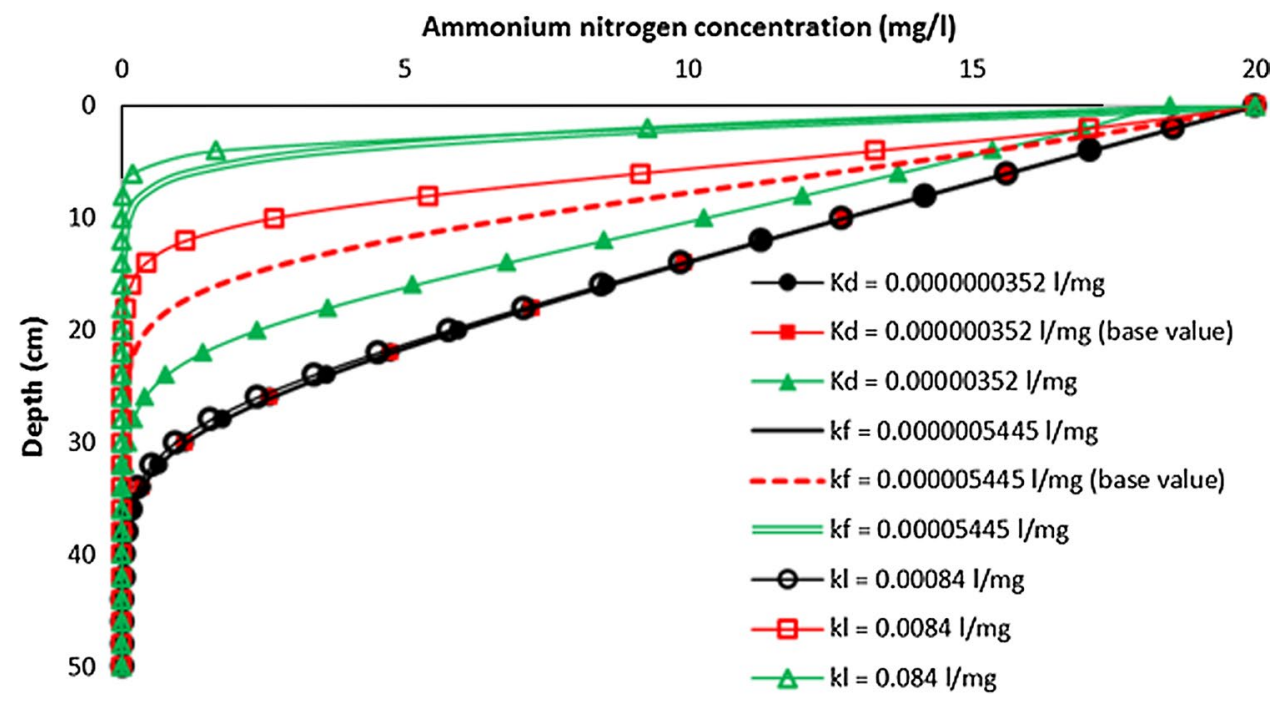

ammonium nitrogen to travel up to $40 \mathrm{~cm}$ depth. The concentration of ammonium nitrogen becomes zero after $40 \mathrm{~cm}$ depth from $20 \mathrm{mg} / \mathrm{l}$ at the soil surface. It is also observed from Fig. 7 that there is a similar observation for ammonium nitrogen when the linear partition coefficient is reduced to one order as compared with the base value. Conversely, a strong reduction in aqueous phase ammonium nitrogen is identified for one-order higher linear partition coefficient than the base value. This is due to the higher sorption rate, which implies that the sorbed concentration of ammonium nitrogen in soil is increased when the partition coefficient is increased. The base value of Freundlich isotherm coefficient $\left(0.5445 \times 10^{-5} \mathrm{l} / \mathrm{mg}\right)$ allows the ammonium nitrogen concentration to travel up to $25 \mathrm{~cm}$ depth. This reduction is identified mainly due to the high sorption rate as compared with the linear partition coefficient and the corresponding Freundlich isotherm constant $\left(n_{f}=1.193\right)$. Furthermore, oneorder lower value and one-order higher value of Freundlich isotherm coefficient from base value permit the ammonium nitrogen concentration to travel up to 35 and $10 \mathrm{~cm}$ depth, respectively. It also observed from Fig. 7 that the concentration of ammonium nitrogen reaches $0 \mathrm{mg} / \mathrm{l}$ at the depth of $18 \mathrm{~cm}$ due to base value of $0.0084 \mathrm{l} / \mathrm{mg}$ Langmuir isotherm coefficient. This is the lowest depth observed for ammonium nitrogen penetration as compared with linear and Freundlich isotherms. Further, the concentration ammonium nitrogen reaches 7 and $37 \mathrm{~cm}$ depth for one-order higher and oneorder lower Langmuir isotherm coefficient from the base
Fig. 8 Concentration of ammonium nitrogen in the presence of various isotherms by ammonium nitrogen and nitrate nitrogen (refer to Tables 2 and 3 for other data)

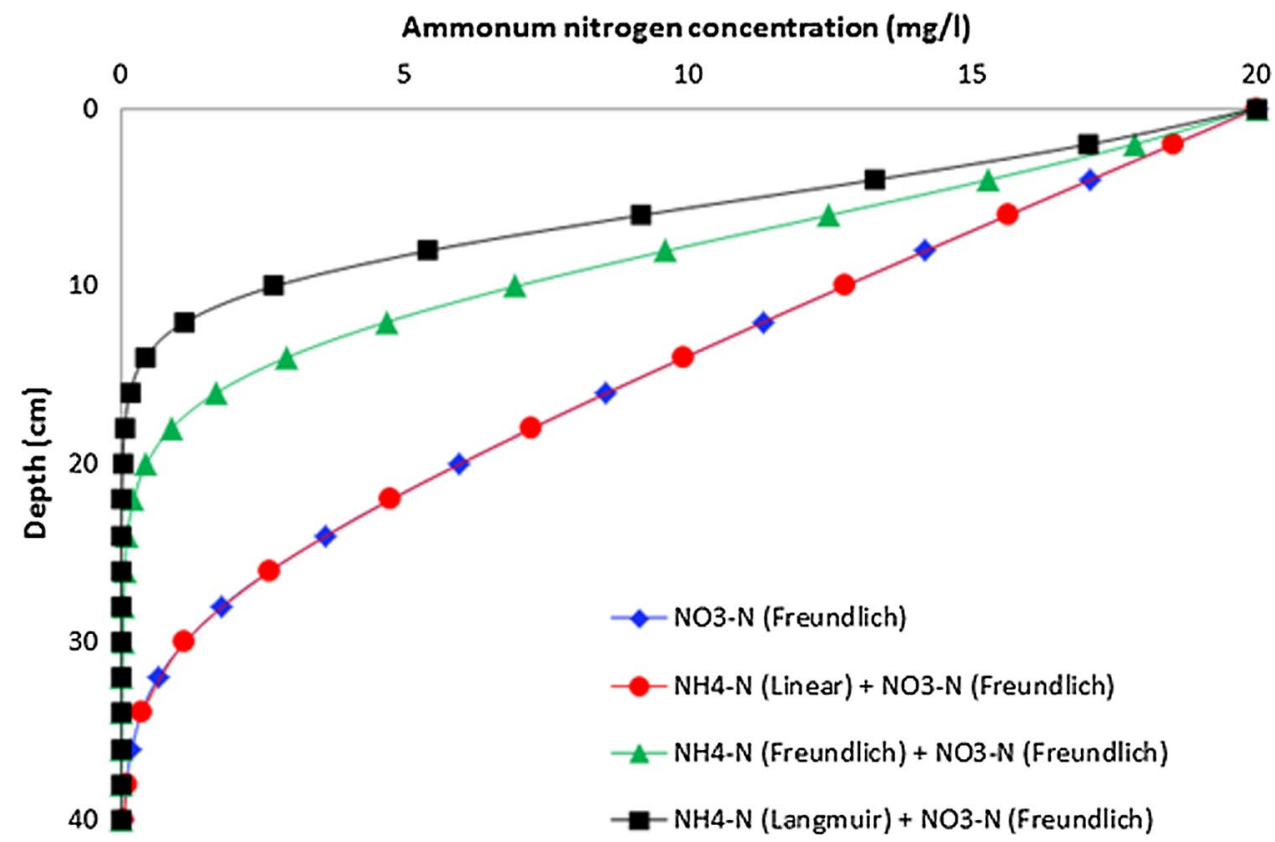


value. It can be concluded from Fig. 7 that the transport depth of ammonium nitrogen is reduced to $37 \%$ by Freundlich isotherm and $55 \%$ by Langmuir isotherm as compared with linear isotherm.

\section{Influence of ammonium nitrogen and nitrate nitrogen sorption on nitrogen species}

In addition to the sorption characteristics by ammonium nitrogen, the impact of nitrate nitrogen sorption is also introduced to analyse the fate and transport of nitrogen species in this section.

Figure 8 provides the spatial variation of ammonium nitrogen in the presence of various isotherms due to ammonium nitrogen and nitrate nitrogen in wastewater-applied agricultural field. In the first scenario, the Freundlich isotherm of nitrate nitrogen is introduced without ammonium sorption. The result shows that the ammonium nitrogen concentration reaches $0 \mathrm{mg} / \mathrm{l}$ at the depth of $40 \mathrm{~cm}$. The second scenario (linear isotherm of $\mathrm{NH}_{4}-\mathrm{N}$ and Freundlich isotherm of $\mathrm{NO}_{3}-\mathrm{N}$ ) also follows the same trend followed by the nitrate nitrogen sorption in the absence of ammonium nitrogen sorption. This shows that the nitrate nitrogen isotherm does not have any impact on ammonium nitrogen transport since the ammonium nitrogen is only transformed into nitrate nitrogen. The third scenario of Freundlich isotherms of both ammonium nitrogen and nitrate nitrogen plays a significant role on the transport of ammonium nitrogen concentration. The third scenario result shows that the ammonium nitrogen concentration spreads up to $25 \mathrm{~cm}$ depth. Similarly, the fourth scenario (Langmuir isotherm of $\mathrm{NH}_{4}-\mathrm{N}$ and Freundlich isotherm of $\mathrm{NO}_{3}-\mathrm{N}$ ) also significantly reduces the depth of movement of ammonium nitrogen up to $18 \mathrm{~cm}$ depth. However, the critical observation between Figs. 4 and 8 clearly confirmed that none of the profiles have the impact of nitrate nitrogen sorption on ammonium nitrogen transport.

The result shows that the Freundlich isotherm of nitrate nitrogen and the combination of linear isotherm of ammonium nitrogen and Freundlich isotherm of nitrate nitrogen have similar trend in the nitrate nitrogen concentration except in the depth between 100 and $200 \mathrm{~cm}$. This small delay in the combined profile (linear isotherm of $\mathrm{NH}_{4}-\mathrm{N}$ and Freundlich isotherm of $\mathrm{NO}_{3}-\mathrm{N}$ ) is due to the addition of linear ammonium nitrogen sorption and the variation which is negligible. Similar reduced trend of nitrate nitrogen concentration profile is found for the combination Freundlich $\mathrm{NH}_{4}-\mathrm{N}$ sorption with Freundlich $\mathrm{NO}_{3}-\mathrm{N}$ sorption and Langmuir $\mathrm{NH}_{4}-\mathrm{N}$ sorption with Freundlich $\mathrm{NO}_{3}-\mathrm{N}$ sorption. Interestingly, the close observation between Figs. 5 and 9 shows that the concentration of nitrate nitrogen is initially increasing from $5 \mathrm{mg} / 1$ to $24 \mathrm{mg} / \mathrm{l}$ and further reduced to $0 \mathrm{mg} / \mathrm{l}$ in the presence of nitrate nitrogen sorption alone and the addition of linear ammonium sorption, whereas there is no major reduction in concentration observed when only the ammonium sorption is considered. Moreover, the peak value of nitrate nitrogen itself reduced consistently in all the cases of ammonium nitrogen and nitrate nitrogen sorption as compared with the absence of nitrate nitrogen sorption. For example, $4 \%$ peak concentration reduction is experienced for linear $\mathrm{NH}_{4}-\mathrm{N}$ sorption alone compared with the combination of linear $\mathrm{NH}_{4}-\mathrm{N}$ sorption with Freundlich $\mathrm{NO}_{3}-\mathrm{N}$ sorption, $7 \%$ peak concentration reduction is experienced for Freundlich $\mathrm{NH}_{4}-\mathrm{N}$ sorption alone compared with the combination of Freundlich $\mathrm{NH}_{4}-\mathrm{N}$ sorption with Freundlich $\mathrm{NO}_{3}-\mathrm{N}$ sorption, and $12.5 \%$ peak concentration reduction
Fig. 9 Concentration of nitrate nitrogen in the presence of various isotherms by ammonium nitrogen and nitrate nitrogen (refer to Tables 2 and 3 for other data)

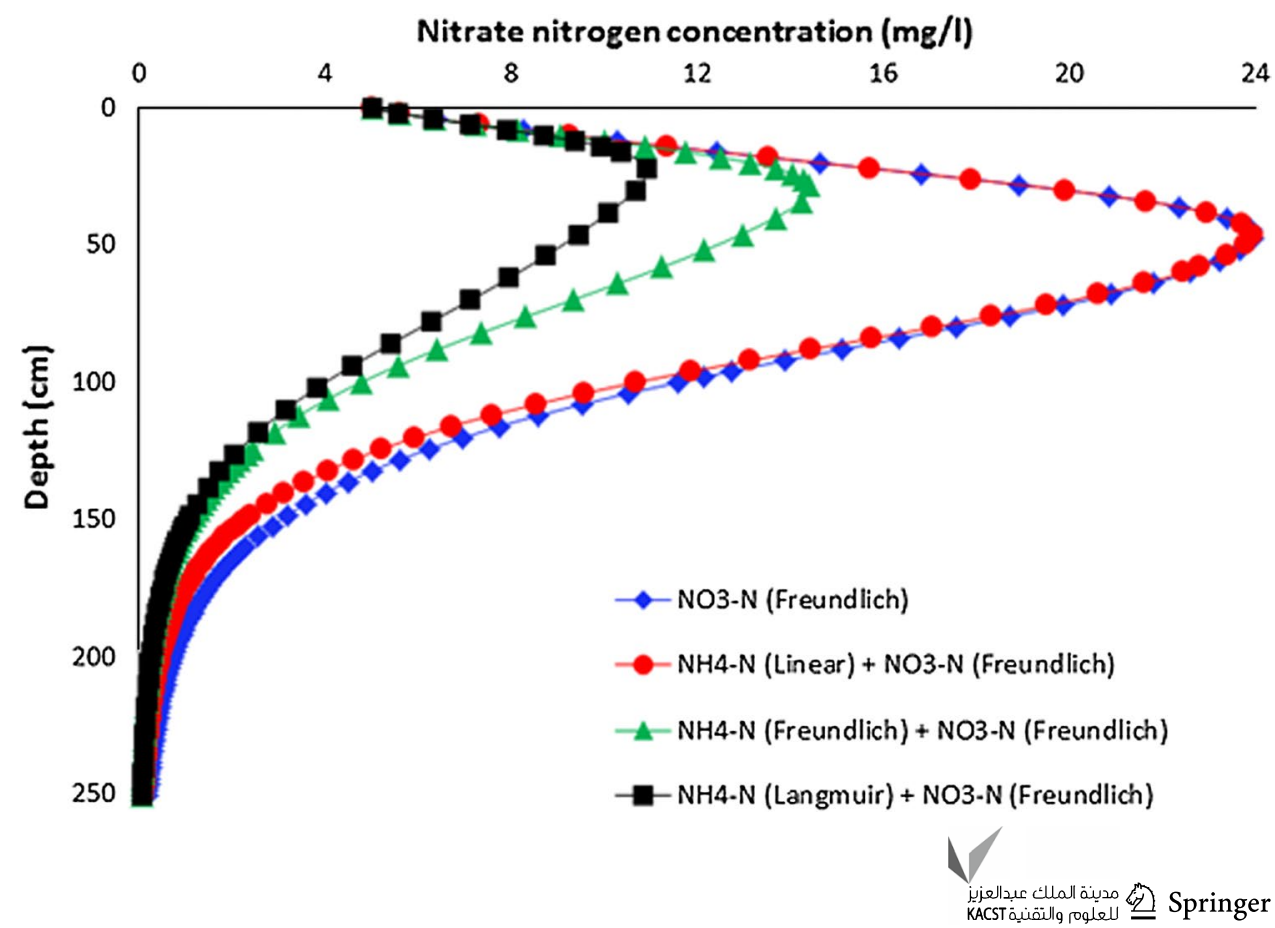


is experienced for Langmuir $\mathrm{NH}_{4}-\mathrm{N}$ sorption alone compared with the combination of Langmuir $\mathrm{NH}_{4}-\mathrm{N}$ sorption with Freundlich $\mathrm{NO}_{3}-\mathrm{N}$ sorption. This shows that the nitrate nitrogen sorption isotherm (Freundlich) has a significant impact on nitrate nitrogen transport. Hence, it can be concluded from Fig. 9 that the combined effect of ammonium nitrogen and nitrate nitrogen sorption isotherms serves to mitigate the nitrate nitrogen contamination of groundwater resource more effectively than the single effect of ammonium nitrogen sorption.

\section{Limitation and uncertainties of the present study}

Numerical experiments have been carried out to study the nitrogen species transport in an agricultural field in the presence of various sorption behaviours such as linear, Langmuir and Freundlich isotherms. Generally, the parameters of each sorption model are depending on adsorbent type and type of contaminant. However, the present numerical experiments of nitrogen species transport in the presence of various sorption isotherms could not be performed with the same adsorbent due to unavailability of laboratory or field data in the literature. The linear and Freundlich parameters for ammonium nitrogen and nitrate nitrogen were selected such a way that the adsorbent soil has relatively high sand content (Lee et al. 2006; Ranjbar and Jalali 2013), whereas the Langmuir parameters were selected from the soil which has high clay content (Buragohain et al. 2013). Generally, the availability of manganese, sulphur and iron in the soil environment can act as electron donors to autotrophic bacteria (Korom 1992; Ayraud et al. 2006; Tesoriero and Puckett 2011) during denitrification process. Hence, the denitrification due to autotrophic bacteria is also to be considered for more realistic field condition. Hence, the results achieved in this study are based on the chosen parameters. However, it is possible to perform the transport of nitrogen species in an agricultural field in the presence of sorption by using the generalized developed model when the different sorption parameters are estimated from same adsorbent.

\section{Conclusions}

In the present study, a numerical model is developed to describe transport of nitrogen species in the wastewaterapplied agricultural field in the presence of various isotherms due to ammonium nitrogen and nitrate nitrogen. In order to simulate the one-dimensional coupled water flow, oxygen diffusive transport, nitrogen species transport, microbial reaction models and sorption kinetics, the implicit finite difference scheme was adopted. The linear, Freundlich and Langmuir isotherms are considered for ammonium nitrogen, and Freundlich isotherm is considered for nitrate nitrogen. From the above study, the following conclusions were arrived:1. $\quad \mathrm{T} \mathrm{h} \mathrm{e}$ ammonium nitrogen concentration movement is prevented drastically in the presence of Langmuir isotherm of ammonium nitrogen as compared with Freundlich and linear isotherms. Similarly, a significant reduction in peak concentration of nitrate nitrogen is observed for Langmuir isotherm of ammonium nitrogen as compared with Freundlich and linear isotherms. This is mainly due to the Langmuir parameters which are estimated from the clay soil and the other isotherm parameters which are selected from relatively high sand content soil.

2. In the presence of Langmuir isotherm of ammonium nitrogen, the peak as well as depth of transport is considerably reduced for nitrite nitrogen and nitrate nitrogen as compared with Freundlich and linear isotherms. However, the Freundlich isotherm has relatively higher impact than linear isotherm on nitrite nitrogen and nitrate nitrogen.

3. Since the mass transfer of oxygen from air phase to aqueous phase is high and the system is completely under oxic condition, the nitrogen gas concentration variation is completely independent from all kinds of sorption isotherms.

4. The downward transport of nitrate nitrogen from agricultural field with wastewater results in higher concentrations at larger depth in the presence of ammonium nitrogen sorption, whereas considerable reduction in concentration is observed when the effect of nitrate nitrogen sorption is included. However, the transport of ammonium nitrogen is completely independent of nitrate nitrogen sorption.

5. The combination of Langmuir isotherm of ammonium nitrogen and Freundlich isotherm of nitrate nitrogen is identified as a best combination of isotherm scenario, which mitigates the nitrate nitrogen contamination in groundwater resources in greater depth.

Essentially, the linear, Freundlich and Langmuir isotherms of ammonium nitrogen and Freundlich isotherm of nitrate nitrogen help to mitigate the movement of all nitrogen species in soil. Particularly, the nitrate nitrogen contamination can be minimized in the groundwater by the combination of Langmuir isotherm of ammonium nitrogen and Freundlich isotherm of nitrate nitrogen.

Open Access This article is distributed under the terms of the Creative Commons Attribution 4.0 International License (http://creativeco mmons.org/licenses/by/4.0/), which permits unrestricted use, distribution, and reproduction in any medium, provided you give appropriate credit to the original author(s) and the source, provide a link to the Creative Commons license, and indicate if changes were made. 


\section{References}

Akosman C, Ozdemir T (2010) Adsorption dynamics and equilibrium studies on nitrate onto various soils. Fresenius Environ Bull 19:2245-2252

Alfnes E, Breedveld GD, Kinzelbach W, Aagaard P (2004) Investigation of hydrogeologic processes in a dipping layer structure 2 . Transport and biodegradation of organics. J Contam Hydrol 69:173-194

Allen-King RM, Grathwohl P, Ball WP (2002) New modeling paradigms for the sorption of hydrophobic organic chemicals to heterogeneous carbonaceous matter in soils, sediments and rocks. Adv Water Resour 25:985-1016

Almasri MN, Kaluarachchi JJ (2007) Modelling nitrate contamination of groundwater in agricultural watersheds. J Hydrol 343:211-229

Antonopoulos VZ (1993) Simulation of water and nitrogen dynamics in soils during wastewater applications by using a finite-element model. Water Res Manag 7:25-237

Ayraud V, Aquilina L, Pauwels H, Labasque T, Wickmann ACP, Aquilina AM, Gallat G (2006) Physical, biogeochemical and isotopic processes related to heterogeneity of a shallow crystalline rock aquifer. Biogeochemistry 81:331-347

Bailey RT, Morway ED, Niswonger RG, Gates TK (2013) Modeling variable saturated multispecies reactive groundwater solute transport with MODFLOW-UZF and RT3D. Groundwater 51(5):752-761

Berlin M, Suresh Kumar G, Nambi IM (2013) Numerical modelling on fate and transport of nitrate in an unsaturated system under non-isothermal condition. Eur J Environ Civ Eng 17(5):350-373

Berlin M, Suresh Kumar G, Nambi IM (2014a) Numerical modeling on the effect of dissolved oxygen on nitrogen transformation and transport in unsaturated porous system. Environ Model Assess 19:283-299

Berlin M, Suresh Kumar G, Nambi IM (2014b) Numerical modelling on transport of nitrogen from wastewater and fertilizer applied on paddy fields. Ecol Model 278:9-85

Berlin M, Suresh Kumar G, Nambi IM (2015) Numerical modeling of biological clogging on transport of nitrate in an unsaturated porous media. Environ Earth Sci 73(7):3285-3298

Birkinshaw SJ, Ewen J (2000) Nitrogen transformation component for SHETRAN catchment nitrate transport modelling. J Hydrol 230:1-17

Buragohain P, Sredeep S, Saiyouri N (2013) A study on the adsorption of ammonium in bentonite and kaolinite. Int J Chem Environ Biol Sci 1(1):157-160

Cahn MD, Bouldin DR, Cravo MS (1992) Nitrate sorption in the profile of an acid soil. Plant Soil 143:179-183

Chen X, Wu H, Wo F (2007) Nitrate vertical transport in the main paddy soils of Tai Lake region, China. Geoderma 142:136-141

DeSimone LA, Howes BL (1998) Nitrogen transport and transformations in a shallow aquifer receiving wastewater discharge: a mass balance approach. Water Resour Res 34(2):271-285

Dubinin MM (1960) The potential theory of adsorption of gases and vapors for adsorbents with energetically non-uniform surface. Chem Rev 60:235-266

El Alfy M (2012) Integrated geostatistics and GIS techniques for assessing groundwater contamination in Al Arish area, Sinai. Egypt Arab J Geosci 5:197-215

Eturki S, Kallali H, Jedidi N, Dhis HB (2012) Ammonium nitrogen removal from synthetic water by treatment with Tunisian natural clay. Desalin Water Treat 49:227-233

Faust CR, Mercer JW (1980) Ground-water modelling: recent developments. Ground water 18(6):569-577

Foo KY, Hameed BH (2010) Insights into the modelling of adsorption isotherm systems. Chem Eng J 156:2-10
Ghiaci M, Abbaspur A, Kia R, Seyedeyn-Azad F (2004) Equilibrium isotherm studies for the sorption of benzene, toluene, and phenol onto organo-zeolites and as-synthesized MCM-41. Sep Purif Technol 40:217-229

Jellali S, Diamantopoulos E, Kallali H, Bennaceur S, Anane M, Jedidi N (2010) Dynamic sorption of ammonium by sandy soil in fixed bed columns: evaluation of equilibrium and non-equilibrium transport process. J Environ Manag 91:897-905

Karickhoff SW (1980) Sorption kinetics of hydrophobic pollutants in natural sediments. Contam Sediment 2:193-205

Khan AR, Ataullah R, Al-Haddad A (1997) Equilibrium adsorption studies of some aromatic pollutants from dilute aqueous solutions on activated carbon at different temperatures. J Colloid Interface Sci 194:154-165

Kizito S, Wu S, Kirui WK, Lei M, Lu Q, Bah H, Dong R (2015) Evaluation of slow pyrolyzed wood and rice husks biochar for adsorption of ammonium nitrogen from piggery manure anaerobic digestate slurry. Sci Total Environ 505:102-112

Koble RA, Corrigan TE (1952) Adsorption isotherms for pure hydrocarbons. Ind Eng Chem 44:383-387

Korom SF (1992) Natural denitrification in the saturated zone: a review. Water Resour Res 28(6):1657-1668

Kumar KV, Sivanesan S (2007) Sorption isotherm for safranin onto rice husk: comparison of linear and non-linear methods. Dyes Pigments 72:130-133

Lafolie F (1991) Modelling water flow, nitrogen transport and root uptake including physical non-equilibrium and optimization of the root water potential. Fertil Res 27:215-231

Langmuir I (1916) The constitution and fundamental properties of solids and liquids. J Am Chem Soc 38(11):2221-2295

Lapidus L, Amundson NL (1952) Mathematics of adsorption in beds. VI. The effect of longitudinal diffusion in ion exchange and chromatographic column. J Phys Chem 56:984-988

Lee ES, Birkham TK, Wassenaar LI, Hendry MJ (2003) Microbial respiration and diffusive transport of $\mathrm{O}_{2},{ }^{16} \mathrm{O}_{2}$, and ${ }^{18} \mathrm{O}^{16} \mathrm{O}$ in unsaturated soils and geologic sediments. Environ Sci Tech 37:2913-2919

Lee MS, Lee KK, Hyun Y, Clement TP, Hamilton D (2006) Nitrogen transformation and transport modeling in groundwater aquifers. Ecol Model 192:143-159

Lin SH, Wu CL (1996) Removal of nitrogenous compounds from aqueous solution by ozonation and ion exchange. Water Res 30:1851-1857

Liu KH, Enfield CG, Mravik SC (1991) Evaluation of sorption models in the simulation of naphthalene transport through saturated soil. Ground Water 29(5):685-692

Lunn RJ, Adams R, Mackay R, Dunn SM (1996) Development and application of a nitrogen modelling system for large catchments. J Hydrol 174:285-304

Malek A, Farooq S (1996) Comparison of isotherm models for hydrocarbon adsorption on activated carbon. AIChE J 42(11):3191-3201

Maraqa MA, Zhao X, Lee J, Allan F, Voice TC (2011) Comparison of nonideal sorption formulations in modeling the transport of phthalate esters through packed soil columns. J Contam Hydrol 125:57-69

Matschonat G, Matzner E (1995) Quantification of ammonium sorption in acid forest soils by sorption isotherms. Plant Soil 168-169:101-995

Mehran M, Noorishad J, Tanji KK (1984) A numerical technique for simulation of the effect of soil nitrogen transport and transformations on groundwater contamination. Environ Geol 5(4):213-218

Millington RJ (1959) Gas diffusion in porous media. Science 130:100-102 
Mitchell RJ, Mayer AS (1998) A numerical model for transient-hysteretic flow and solution transport in unsaturated porous media. $\mathrm{J}$ Contam Hydrol 50:243-264

Moradzadeh M, Moazed H, Sayyad G, Khaledian M (2014) Transport of nitrate and ammonium ions in a sandy loam soil treated with potassium zeolite-evaluating equilibrium and non-equilibrium equations. Acta Ecol Sin 34:342-350

Morell I, Padilla F, Albertoo JM (1996) Modelling of leaching of chloride and nitrogen species in an experimental citrus grove. Ecol Model 87:235-247

Myers AL, Prausnitz JM (1965) Thermodynamics of mixed gas adsorption. AIChE J 11(1):121-129

Natarajan N, Suresh Kumar G (2015) Numerical modeling and spatial moment analysis of solute transport with Langmuir sorption in a fracture matrix coupled system. ISH J Hydraul Eng 21(1):28-41

Overman AR (1975) Ion transport through sand by convective diffusion. Plant Soil 43:663-670

Ozturk N, Bektas TE (2004) Nitrate removal from aqueous solution by adsorption onto various materials. J Hazard Mater B112:155-162

Pinder GF (1984) Groundwater contaminant transport modelling. Environ Sci Tech 18:108A-114A

Rahil MH, Antonopoulos VZ (2007) Simulating soil water flow and nitrogen dynamics in a sunflower field irrigated with reclaimed wastewater. Agric Water Manag 92:142-150

Rahnama MB, Zamzam A (2013) Quantitative and qualitative simulation of groundwater by mathematical models in Rafsanjan aquifer using MODFLOW and MT3DMS. Arab J Geosci 6:901-912

Ranjbar F, Jalali M (2013) Measuring and modelling ammonium adsorption by calcareous soils. Environ Monit Assess 185:3191-3199

Reddy KR, Patrick WH (1975) Effect of alternate aerobic and anaerobic conditions on redox potential, organic matter decomposition and nitrogen loss in a flooded soil. Soil Biol Biochem 7:87-94

Reible DD, Malhiet ME, Illangasekare TH (1989) Modelling gasoline fate and transport in the unsaturated zone. J Hazard Mater 22:359-376

Saadi Z, Maslouhi A (2003) Modelling nitrogen dynamics in unsaturated soils for evaluating nitrate contamination of the Mnasra groundwater. Adv Environ Res 7:803-823

Sekhar M, Suresh Kumar G (2006) Modeling transport of linearly sorbing solutes in a single fracture: asymptotic behavior of solute velocity and dispersivity. Geotech Geol Eng 24(1):183-201
Sekhar M, Suresh Kumar G, Mishra D (2006) Numerical modeling and analysis of solute velocity and macrodispersion for linearly and nonlinearly sorbing solutes in a single fracture with matrix diffusion. J Hydrol Eng 11(4):319-328

Sharifnia S, Khadivi MA, Shojaeimehr T, Shavisi Y (2016) Characterization, isotherm and kinetic studies for ammonium ion adsorption by light expanded clay aggregate (LECA). J Saudi Chem Soc 20:S342-S351

Simunek J, Suarez DL (1994) Two-dimensional transport model for variably saturated porous media with major ion chemistry. Water Resour Res 30:1115-1133

Sips R (1948) Combined form of Langmuir and Freundlich equations. J Chem Phys 16:490-495

Soleimani S, Van Geel PJ, Isgor OB, Mostafa MB (2009) Modeling of biological clogging in unsaturated porous media. J Contam Hydrol 106:39-50

Suresh Kumar G (2009) Influence of sorption intensity on solute mobility in a fractured formation. J Environ Eng 135(1):1-7

Suresh Kumar G, Sekhar M, Mishra D (2008) Time dependent dispersivity of linearly sorbing solutes in a single fracture with matrix diffusion. J Hydrol Eng 13(4):250-257

Tesoriero AJ, Puckett LJ (2011) O2 reduction and denitrification rates in shallow aquifers. Water Resour Res 47(W12522):1-17

Toth J (1971) State equations of the solid gas interface layer. Acta Chem Acad Hung 69:311-317

Van Dam JC, Feddes RA (2000) Numerical simulation of infiltration, evaporation and shallow grounwater levels with the Richards equation. J Hydrol 233:72-85

Vasudevan M, Kumar GS, Nambi IM (2015) Numerical studies on kinetics of sorption and dissolution and their interactions for estimating mass removal of toluene from entrapped soil pores. Arab J Geosci 8(9):6895-6910

Vijayaraghavan K, Padmesh TVN, Palanivelu K, Velan M (2006) Biosorption of nickel(II) ions onto Sargassum wightii: application of two-parameter and three parameter isotherm models. J Hazard Mater B133:304-308

Publisher's Note Springer Nature remains neutral with regard to jurisdictional claims in published maps and institutional affiliations. 